\title{
Earnings Management During Antidumping Investigations In Europe: Sample-Wide And Cross- Sectional Evidence ${ }^{+}$
}

\author{
David Godsell \\ Michael Welker \\ Ning Zhang
}

This draft: January 3, 2017

\begin{abstract}
This paper examines earnings management by European Union firms that initiate an antidumping investigation. We first document economically and statistically significant income decreasing earnings management around the initiation of an antidumping investigation. We show that earnings management increases when accounting data directly affect the magnitude of the tariffs imposed in the trade investigation. We also find that earnings management decreases as the number of petitioning firms increases or as the distance between petitioning firms increases, suggesting free-rider and coordination problems. We find that earnings management increases when the petition is directed at a country that imports more goods from the petitioning firm's home country, suggesting retaliation threats affect incentives. We document that raising equity or debt financing moderates income decreasing earnings management, consistent with the idea that sample firms trade off capital market and regulatory considerations. Our results indicate that contemporary research methods can detect accruals based earnings management in settings in which the incentives for earnings management can be clearly identified.
\end{abstract}

Keywords: earnings management, trade regulation, antidumping investigations, European Union

JEL Codes: M41; M48; F13

\footnotetext{
+ Accepted by Christian Leuz. Godsell is from the University of Illinois at Urbana-Champaign and Welker and Zhang are from Queen's University in Canada. We are grateful to Marc Busch for assistance in understanding trade regulations and data. We also acknowledge helpful comments on the manuscript from a very constructive and helpful anonymous referee, workshop participants from Virginia Tech, Hong Kong Polytechnic University, the University of Waterloo, Miami University of Ohio and the University of Toronto, Agnes C.S. Cheng, Giorgio Gotti, Hollis Skaife, Ole-Kristian Hope, Hans Christensen, Mark Maffett, Eddie Riedl, a reviewer for the International Accounting Section Mid-Year Meeting, and participants at the 2014 Global Issues in Accounting Conference at UNC-CH, the International Accounting Section Mid-year Meeting and the 2016 Journal of Accounting Research conference. We especially thank Anya Kleymenova who provided particularly detailed and institutionally rich comments. We are also grateful to Bureau van Dijk for making their ORBIS database available to us to support this research. We acknowledge funding from the Social Science and Humanities Research Council of Canada (SSHRCC) and the Smith School of Business at Queen's University. Welker acknowledges financial support from the KPMG fellowship at Queen's University. An Online Appendix to this paper can be downloaded at http://research.chicagobooth.edu/arc/journalof-accounting-research/online-supplements.
}

* Correspondence author: e-mail: mw18@queensu.ca; telephone: (613) 533-2317. 


\section{Earnings Management During Antidumping Investigations In Europe: Sample-Wide And Cross- Sectional Evidence}

\section{Section 1 - Introduction}

Earnings management occurs when management uses the flexibility inherent in accounting standards to manage the firm's reported accounting earnings to influence some economic outcome to the firm's (or management's) benefit (Schipper, 1989). This paper examines earnings management in European Union (EU) firms initiating antidumping trade investigations. The antidumping investigation process in the EU makes extensive use of the accounting data of firms that initiate investigations, and that accounting data is collected as part of the investigation process. As a result the use of accounting data in the antidumping investigation process is well known and predictable so firms initiating investigations would know that their accounting data would affect the outcome of their investigation. Therefore the antidumping investigation setting allows for the clear identification of the incentives it provides for earnings management and is an excellent setting to examine accruals based earnings management.

Antidumping investigations in the EU (and elsewhere) involve two key determinations. First, the prices at which foreign exporters are selling goods in the EU are compared to the goods' normal values to determine if goods are being dumped into the EU. ${ }^{1}$ Second, the financial performance of the allegedly affected domestic EU industry is examined to determine if the domestic industry has suffered financial injury as a result of the dumping. When both dumping and material injury are present, duties on the goods imported into the EU are assessed. These duties make the products of the domestic industry more competitive and financially benefit the domestic industry. This setting provides clear incentives for the domestic industry to engage in income decreasing earnings management to enhance the likelihood of an affirmative injury decision.

In a seminal study in the accounting literature, Jones (1991) examines a small sample of companies that requested import relief in five industries in the United States between 1980 and 1985 and finds evidence suggesting that firms manipulate their accounting data to report diminished profitability in the year in which the trade investigation is concluded. Jones' (1991) work has spawned tremendous interest in earnings management, including application and extension of her model in a variety of contexts. Debates over the existence, magnitude

\footnotetext{
${ }^{1}$ Normal value is typically the price of the product allegedly dumped when sold in the exporting country market.
} 
and measurement of earnings management in this extensive literature continue today. ${ }^{2}$ Despite this voluminous follow up work, there has been almost no additional work that investigates whether and how earnings management occurs during trade investigations in contemporary periods and in other jurisdictions around the world. The EU setting of our study also allows an examination of several economic predictions about cross-sectional variation in earnings management that are new to the literature.

There have been a variety of studies that examine earnings management in other regulatory settings that produce similar incentives to manage earnings to report lower profitability. Most of these studies are conducted using data from the United States. This literature has typically examined regulated industries or circumstances in which high profitability could prompt political scrutiny and costs (e.g., Cahan (1992), Mensah, Considine and Oakes (1994), Key (1997), Han and Wang (1998), Monem (2003) and Johnston and Rock (2005)).

Our research is closely related to studies that examine earnings management in jurisdictions outside the United States. Leuz, Nanda and Wysocki (2003) document that earnings management proxies suggest less earnings management in countries with better developed stock markets that have more dispersed ownership, and better legal enforcement and investor protection. Gopalan and Jayaraman (2012) extend Leuz et al. (2003) and find that insider controlled firms exhibit more earnings management in countries with weak investor protection. Francis and Wang (2008) also find an association between earnings management and investor protection that is concentrated in firms using Big 4 auditors. Because these international studies examine earnings management in broad samples of public firms, the researchers generally have no prior beliefs regarding if, when or how firms in these broad samples might face incentives to manage earnings to achieve a particular economic outcome. As a result, it is difficult to infer whether the evidence provided in these studies is consistent with earnings management or with variation in accruals caused by other factors, including differences in the informativeness of earnings. More generally, there is debate about whether discretionary accruals do indeed reflect earnings management.

In contrast, in the trade investigation setting, we are able to identify which firms have incentives to manage earnings, and when and how they would manage earnings in order to increase the likelihood of receiving trade

\footnotetext{
${ }^{2}$ Since the subsequent earnings management literature has not focused on trade investigations and is very extensive, we do not provide a detailed review of this literature here. This broad literature and the influence of the original Jones (1991) article on this literature are discussed in Dechow, Ge and Schrand (2010). The only studies that examine potential earnings management in trade investigations are Rayburn and Lenway (1992) who examine sixteen U.S. semiconductor manufacturers during 1985 and Magnan, Nadeau and Cormier (1999) who examine 17 Canadian firms during 1976 to 1992.
} 
remedies and the economic magnitude of those remedies. As we detail later, the process by which injury is determined and the procedure for assessing duties provide clear incentives to engage in predictable earnings management in the periods surrounding the initiation of an antidumping investigation. While our study utilizes smaller samples than much of the past literature, we are able to make directional predictions about earnings management during particular periods that have not been possible in most of the prior literature examining earnings management in international settings.

We choose to examine firms initiating trade investigations in the EU for several reasons. First, there is a single regulatory process in place that governs how all antidumping investigations are conducted in the EU. This allows us to investigate a number of interesting sample partitions to see what factors are associated with crosssectional variation in earnings management while holding constant the regulatory setting that gives rise to the earnings management incentives. The regulatory process governing trade investigations in the EU can determine assessed duties based on the extent of injury (allegedly) suffered by domestic petitioners, providing enhanced incentives for earnings management in those cases. In addition, the EU setting provides interesting variation in the number of firms within the EU that initiate investigations, the distance between those firms and in the export intensity of the countries that are home to petitioning firms. The EU setting allows us to investigate the effects of these setting specific incentives on earnings management, enhancing confidence that our analysis is documenting earnings management in response to the incentives provided in the setting. In addition, we are able to assess the effects of country level institutions such as legal enforcement and regulatory quality while holding constant the regulatory process that produces the incentives for earnings management in our setting.

We develop our hypotheses by analyzing the trade investigation process. The injury decision involves systematically comparing accounting data prior to the initiation of the antidumping claim with accounting data in the year, and in some cases, the year after or year before, the investigation is launched. Deteriorating accounting performance around the time the claim is filed is viewed as evidence consistent with the domestic industry being injured by the dumping of competing foreign products into the EU marketplace. This injury determination process is dictated by WTO guidelines and would be very transparent and predictable to petitioning firms. Hence, we posit that EU firms petitioning for trade remedies in antidumping investigations have strong incentives to engage in income decreasing earnings management in the year of and year subsequent to their petition for trade relief. 
Sample-wide we find income decreasing earnings management in the year closest to the date the antidumping investigation is initiated and the following year, and our estimates of earnings management suggest that on average discretionary accruals contribute to more than a one percent decline in return on assets during these periods for sample firms. We consider that magnitude of decline to be economically as well as statistically significant. ${ }^{3}$ Our sample-wide evidence of income decreasing discretionary accruals is only present in time periods right around the initiation of the investigation, enhancing confidence that our tests are identifying earnings management. Our base tests include a number of features that should enhance our ability to separate earnings management from actual economic injury, and we perform a number of additional analyses that help ensure that our test results do not simply reflect actual injury resulting from dumping.

We also document a number of cross-sectional patterns in this earnings management activity. We examine two types of factors that could affect the incentives for earnings management in our setting. First, we examine some previously unexplored factors that could impact the costs and benefits of earnings management that are specific to our setting. Second, we revisit some factors that the previous literature has found are associated with earnings management to see if these factors impact earnings management in our setting. Our first set of case specific variables includes a measure of the extent to which petitioning firms' accounting data directly affects the magnitude of import relief provided in successful cases, the number of firms petitioning for import relief and the distance between them as proxies for coordination costs and the export intensity of the country that is home to the petitioning firm(s) as a proxy for retaliation capacity.

We find that earnings management is more pronounced in cases in which the petitioning firms' accounting data directly affect the magnitude of the tariffs imposed in the trade investigation. In antidumping investigations in the EU, the European Commission calculates two margins: a dumping margin that measures the deviation of the sales price charged for the dumped goods in the EU from the goods' normal value and an injury elimination margin that measures the duty that would have to be applied to the foreign goods in order to remove the injury to the domestic industry. Importantly, the ultimate duty applied is the lower of the dumping margin and the injury

\footnotetext{
${ }^{3}$ For comparison, from Table 6 in Jones (1991) we compute the mean abnormal accruals in year zero in her sample to be negative 5.85\%. Of course our model includes many terms not included in her model enhancing our ability to distinguish normal from discretionary accruals. The large magnitude of discretionary accruals in some prior work such as Jones (1991) is one source of skepticism that accruals based tests actually identify earnings management (Ball, 2013).
} 
elimination margin. This decision is made individually for each foreign exporter, or in some cases, for each foreign country where foreign exporters are domiciled. As a result, any given antidumping case may have some defendants assigned an injury elimination margin and some defendants assigned a dumping margin. If petitioning firms from the domestic industry can anticipate which margin will be lower, then the incentives to engage in earnings management are stronger when injury elimination margins are used to determine the tariffs for a greater proportion of the defendants as these margins are a direct function of the petitioning firms' accounting data. We find that earnings management is more pronounced when a greater proportion of the tariffs assigned in the case are based on injury elimination margins.

In addition, we find that the income decreasing earnings management around case initiation is less pronounced in cases involving a greater number of sample petitioning firms. Among those cases that involve two or more sample petitioning firms, we find that earnings management is less pronounced in cases in which there is greater distance between the petitioners. These results suggest that either free-rider problems or coordination costs are more severe when more firms are involved or when firms are more distant, limiting the earnings management undertaken by petitioning firms. To the best of our knowledge, this is the first evidence in the accounting literature that free-rider problems or coordination costs affect earnings management incentives. We also find that earnings management is exacerbated when the country that is home to the petitioning firm has a high level of exports to the country(ies) charged in the petition with dumping goods into the EU. This result is consistent with the idea that regulators are reluctant to impose tariffs on countries with strong capability to retaliate, and that petitioning firms manage earnings more to enhance the apparent injury and increase their probability of success in these cases.

Our second set of cross-sectional variables includes external financing needs and country level regulatory institutions because the prior literature suggests both could affect earnings management incentives. We identify firms that raise new debt or equity financing in the year of and/or the year after the initiation of an antidumping investigation, and find that income decreasing earnings management in those years is moderated for this set of firms. This result is consistent with the literature that suggests that reporting incentives play an important role in influencing financial reporting decisions and highlights the tradeoff between regulatory and capital market based incentives (Ball, Robin and Wu, 2003; Burgstahler, Hail and Leuz, 2006). We find that earnings management during trade investigations does not differ between countries with better legal enforcement or regulatory quality 
and countries with worse legal enforcement and regulatory quality. We find similar results when we partition our sample on measures that explicitly capture auditing and financial reporting related enforcement.

On the surface this evidence appears to contradict the past literature that better legal enforcement or regulatory quality generally moderates earnings management. We conjecture that this difference from the prior research findings is a result of the type of earnings management we document. Most prior studies examine broad samples in which any earnings management occurring is likely to be income increasing, decreasing transparency and potentially harming investors. In our setting firm stakeholders other than consumers will benefit from import relief if the antidumping case is successful. In addition, the expected earnings management is income decreasing. Therefore it is not clear that better regulatory and legal institutions would constrain the type of earnings management we document if regulators are incented to be attentive to income increasing earnings management that is detrimental to stakeholders other than management (Dechow, Ge, Larson and Sloan, 2011). It is also possible that prior international studies using broad samples of firms capture cross-country variation in earnings informativeness that is shaped by regulatory and legal institutions that create incentives to provide more or less informative accounting numbers, but do not capture earnings management. If this is true the results from the prior literature might be best interpreted as evidence that regulatory and legal institutions affect overall earnings informativeness in the country rather than earnings management per se.

The most interesting results of our study come from our consideration of the process through which petitioning firms prepare petitions and through which regulators use accounting data in the trade investigation. Our evidence that earnings management increases with the likelihood of regulators basing tariffs on the petitioners' accounting data, increases with the ability of the defendant country(ies) to retaliate, and decreases as the number of petitioning firms increases or as the distance between petitioners increases and therefore coordination costs increase provide novel and unique insights to the earnings management literature. Collectively these findings suggest that a thorough understanding of the incentives facing firms can significantly increase the power of research designs that examine the prevalence and magnitude of earnings management in economically motivated settings. We encourage further work in which a thorough understanding of the incentives for earnings management is incorporated in the research design. 
Our study makes several contributions to the accounting literature. First, our main results update and expand the analyses reported by Jones (1991) and suggest that earnings management during import relief investigations continues in a contemporary European Union sample. Given the importance of the Jones (1991) paper to the accounting literature, we believe this update and extension of her analysis is important. Her original evidence is based on a small sample (23 firms, 14 of which are petitioning firms) from a single jurisdiction (U.S.) in the early 1980s, over 30 years ago. The only additional work examining trade investigation settings (Rayburn and Lenway (1992) and Magnan, Nadeau and Cormier (1999)) is also based on very small and dated samples in the U.S. and Canada, respectively. Given the importance of trade regulation to the world economy and the systematic liberalization of international trade since the 1980s, additional evidence on the use of accounting data in trade regulation, and the incentives trade regulations create, seems warranted. Our results suggest systematic biases in the data used in antidumping investigations and have clear implications for international trade scholars and regulators. In addition, the models used to detect earnings management have advanced considerably since Jones (1991) and our paper provides important feedback about the ability of current research methods to detect accruals based earnings management in settings in which the timing and direction of the incentives for earnings management can be identified.

\section{Section 2 -Description of the setting, prior literature, and hypotheses}

Antidumping investigations in the EU are generally initiated after receiving a complaint from producers of a homogeneous product in the European Community (hereafter the Community) alleging that non-EU domiciled foreign exporters are dumping a like product in the EU. Blonigen and Prusa (2003) review the antidumping literature and report that industry specific factors such as import penetration, industry employment, capital intensity and industry concentration and macro-economic factors such as GDP growth and currency fluctuations are associated with firms' decisions to initiate an investigation. The European Commission is responsible for investigating antidumping allegations, and the process begins with a decision about whether or not the evidence provided in the complaint warrants an investigation. This decision must be made within 45 days of receiving the complaint. Importantly, the complaint filed by the EU producers must provide detailed information about the alleged dumping including evidence of dumping, injury, and a causal link between the two so that this information is available to the European Commission to inform the initiation decision. 
The European Commission consists of 28 commissioners, one from each EU member state. The commissioners are charged with representing the interests of the EU as a whole rather than promoting the interests of their home state. The member states are consulted during the investigation, but their views are not binding on the European Commission. If the European Commission proposes the imposition of tariffs on foreign exporters, then the European Council votes on the proposal. The European Council is composed of the heads of state of the EU member states. While the votes of the European Council are not publicly recorded, Evenett and Vermulst (2005) construct some voting results from newspaper articles and offer an interesting account of voting patterns across countries. They identify six strategies that the European Commission takes to increase the number of member states that support the imposition of antidumping duties, including reducing the magnitude of duties and narrowing the scope of products included in the investigation. They also identify eight diplomatic factors that influence the voting behavior of member states, including direct lobbying of EU member states by important trading partners and threats of retaliation by important trading partners. Evenett and Vermulst (2005) show that political factors and the interests of member states affect antidumping investigations at the European Council level if not before.

When the European Commission decides to investigate a complaint, it publishes a notice in the EU's Official Journal indicating it is opening an investigation. The European Commission then sends questionnaires to both EU producers and to the exporting firms accused of dumping to gather information that will aid in the investigation. An investigation into an allegation that foreign companies are dumping products involves two critical determinations. First, the European Commission must determine whether foreign goods are in fact being sold below fair market value into their jurisdiction. This involves a comparison of the prices at which the foreign entities are selling goods in the EU with the goods' normal value. Typically, normal values are the prices at which the foreign exporter sells goods in its own domestic market. In some cases, the exporter has insufficient sales in its domestic market, the foreign entity's domestic market is deemed to be a non-market economy, or the prices in that market are deemed to be below unit production costs plus selling, general and administrative expenses. In these cases, the determination of whether dumping is taking place is based either on the prices at which the goods are sold in a third (or proxy) market, or based on a constructed normal value. The constructed normal value of the good is the "cost of production in the country of origin plus a reasonable amount for selling, general and 
administrative costs and for profits." ${ }^{4}$ The accounting data of the foreign producers would be used to determine constructed normal values. The foreign producers are given incentive to cooperate with the investigation in the EU because the European Commission makes it clear that "the consequences of non-cooperation normally lead to the imposition of measures which are higher than for parties which have cooperated." ${ }^{5}$

The second determination is whether the domestic producers of the goods have been injured by the alleged dumping. This is the key determination that provides firms seeking trade relief with incentives to manage their earnings to demonstrate diminished profitability and therefore injury. This determination is based on the volume of dumped goods compared to the total domestic market, the effect of the dumped imports on prices in that market, and the impact of the dumped imports on the domestic industry. The extent to which the dumped imports have negatively impacted the domestic industry is based on "an evaluation of all relevant economic factors and indices having a bearing on the state of the industry, including the fact that an industry is still in the process of recovering from the effects of past dumping, the magnitude of the actual margin of dumping, actual and potential decline in sales, profits, output, market share, productivity, return on investments, utilization of capacity, factors affecting ... prices; actual and potential negative effects on cash flow, inventories, employment, wages, growth, ability to raise capital or investments. This list is not exhaustive, nor can any one or more of these factors necessarily give decisive guidance."

The injury decision typically involves the assessment of changes in industry financial condition during an investigation period. While there is some variation in exactly how this investigation period is defined, the typical case uses an investigation period of approximately two years, and this investigation period typically ends at some time in the year before or the year after the trade investigation is initiated. Usually deteriorating financial performance between the two years of the investigation period and the two years prior to the investigation period is cited as evidence of injury. It is clear that the determination of injury to domestic producers involves the extensive use of affected domestic producers' accounting data.

\footnotetext{
${ }^{4}$ This definition, which comes from European Council Regulation No. 1225/2009, Article 2, section 3, conforms to the definition in the World Trade Organization guidelines. The Regulation is available at http://trade.ec.europa.eu/doclib/docs/2010/april/tradoc_146035.pdf.

5 "Investigations" available at http://trade.ec.europa.eu/doclib/docs/2013/april/tradoc_151022.pdf.

${ }^{6}$ European Council Regulation No. 1225/2009, Article 3, section 5.
} 
Jones (1991) provides an extensive discussion of the incentives that petitioning firms have to manage their accounting data to provide more compelling evidence that injury exists in trade cases. ${ }^{7}$ The incentives to report less profitable operations during an antidumping investigation may conflict with other incentives managers may have, e.g., to report inflated profitability to appease shareholders, or due to debt covenants or compensation agreements. However, because all parties that contract with the firm (with the exception of consumers) stand to benefit if the firm receives a favorable ruling, these incentives to report inflated profitability are likely to be outweighed on average by the incentives to report diminished profitability during the investigation period. ${ }^{8}$ Regulators overseeing the antidumping investigation are unlikely to have incentives to "undo" any earnings management because it is unlikely that consumers will find it cost effective to organize and lobby the regulator to do so. ${ }^{9}$ Thus, trade investigations provide powerful incentives to report poor financial performance. To provide a more complete understanding of the trade investigation process, we present a description of one case in detail in the appendix.

In our study, we build upon and extend Jones (1991) in several ways. We first update her analysis to examine much more recent data. Much has changed both in the world of international trade and in accounting since the mid-1980s, not least being the advent of the WTO and its stricter terms on antidumping methodology (Barton, Goldstein, Josling and Steinburg, 2006). Therefore, it is ex ante not clear if the original Jones (1991) findings are descriptive of current practice.

Second, the original Jones (1991) study examines only trade investigations that were initiated in the United States. Since the United States has arguably the most stringent accounting standards and enforcement in the world, it could be argued that Jones (1991) evidence provides a lower bound on the extent to which accounting

\footnotetext{
${ }^{7}$ While Jones (1991) discusses antidumping investigations, her empirical analysis focuses on "general escape clause" trade investigations in the United States. These investigations did not require that dumping by foreign producers be proven. She argues that the incentives to understate accounting data to show injury are even greater in general escape clause investigations than in antidumping investigations because the extent of injury required to get trade relief is higher in general escape clause investigations. While this may be true, the incentives to understate accounting data to demonstrate injury in antidumping cases still clearly exist. We examine antidumping cases because data on these cases are available internationally.

${ }^{8}$ Outcomes other than the imposition of antidumping duties include rejection of the application for trade remedy, an undertaking (a price agreement) established between the European Commission and the exporter, or the withdrawal of the application for trade relief by the petitioner (this may be caused for any number of reasons, e.g., lack of petition support from industry peers, inadequate evidence to support claims or the establishment of a private sector agreement satisfactory to the petitioner (see, e.g., Prusa (1992) and Staiger and Wolak (1994))).

${ }^{9}$ Blonigen and Prusa (2003, p. 11) describe the process by which injury is determined in the U.S. as follows: "Somewhat like the definition of pornography, they apparently know injury when they see it... Trends analysis is common, but this essentially means eyeballing charts and tables and confirming profits and employment are down. If imports have also increased, the causality connection is assumed."
} 
data are managed internationally in response to trade investigations. International investigations of earnings management across a wide range of countries generally find that the United States has the best, or among the best, earnings quality, with the least evidence of earnings management, in the world (Leuz et al. (2003), Bhattacharya, Daouk and Welker (2003)). Our work sheds light on trade investigations in the EU to provide evidence about whether the management of accounting data during trade investigations exists outside the United States. Our initial baseline specification includes indicator variables for particular years relative to the date the trade investigation is initiated. We predict income decreasing earnings management in period $t$ and $t+1$ relative to the year in which the petition is filed. We include year indicators for periods $t-3$ and $t-2$ because these periods are often used as benchmarks in assessing the extent of the injury experienced in the petitioning firms' industry. If petitioning firms plan the initiation of their investigation far in advance, there would be incentives to engage in income increasing earnings management during these baseline periods to exaggerate the injury calculation. ${ }^{10} \mathrm{We}$ also include an indicator variable for period $t$-1, though predicting what type of earnings management would be incented in trade investigations during this period is more difficult because sometimes this period in included in the pre-injury baseline period, and sometimes it is included in the injury investigation period. In addition, we include terms for periods $t+2$ and $t+3$ to capture any reversal of the income decreasing earnings management occurring in periods $t$ and $t+1$ (Dechow, Hutton, Kim and Sloan, 2012). The optimal earnings management pattern in this setting would be to inflate earnings in periods $t-3$ and $t-2$, then have this income increasing earnings management reverse during periods $t$ and $t+1$, exaggerating the perceived injury due to dumping. If this pattern is what we observe, then there would not be reversals in periods $t+2$ and $t+3$ because the accrual reversal would occur in periods $t$ and $t+1$. In order to limit the number of indicator variables included in our subsequent empirical testing, we also present baseline results that collapse periods $t-3, t-2$ and $t-1$ into a new variable (Pre) capturing average earnings management during the pre-injury baseline period, periods $t$ and $t+1$ into a new variable (Current) capturing the

\footnotetext{
${ }^{10}$ This notion is anticipated by several authors in early work. For example, Hillman, Katz and Rosenberg (1987) develop a model in which firms hire excessively in up market conditions so they can point to the dismissal of larger numbers of workers when responding to an import shock, thereby increasing the likelihood of a positive injury determination. Leidy and Hoekman (1991) also suggest strong incentives for petitioning firms to "orchestrate the appearance of injury", leading to their theory of spurious injury. These papers sit in a broader literature to which our paper relates which studies directly unproductive profit seeking or rent seeking, a general concept first outlined by Bhagwati (1982).
} 
average earnings management during the injury investigation period, and periods $t+2$ and $t+3$ into a new variable (Post) to capture any reversal of earnings management that occurs during the post injury determination period.

Our first hypothesis predicts that petitioners in trade investigations engage in earnings management around the time of the investigation. We expect to see the strongest results during the Current time period in our tests but our specifications also test for earnings management before and after that primary test period.

We next consider case-based incentives that vary across firms. The process of assigning duties in antidumping trade investigations in the EU follows a two-step process. The European Council regulation describing protections against dumped imports in the EU notes that "the amount of the antidumping duty shall not exceed the margin of dumping established but it should be less than the margin if such lesser duty would be adequate to remove the injury to the Community industry". ${ }^{11}$ In other words, two potential duties are calculated, a dumping margin and an injury elimination margin, and the final duties assessed in the case are the lower of these two margins. The dumping margin is defined in the European Council regulation as "the amount by which the normal value exceeds the export price". ${ }^{12}$ Normal values are prices paid in arms-length transactions in the exporting country, though in some circumstances a constructed normal value or a proxy country normal value are used. The export price is defined in the European Council regulation as "the price actually paid or payable for the product when sold for export from the exporting country to the Community", though again there are circumstances in which adjustments are made in arriving at this price. ${ }^{13}$ The regulations do not provide detailed guidance indicating how the injury elimination margin is to be calculated, but anecdotally from our review of decisions this is often calculated as the increase in price needed to bring the industry back to the profitability levels that existed prior to the injury investigation period.

We assume that the firms initiating a trade investigation would have reasonable foresight about whether injury elimination margins or dumping margins are likely to be the predominantly used margins in their case. We believe that this assumption is reasonable because the petitioning firms have to gather data that would allow them to estimate both the injury elimination and dumping margins in their case. Petitioning firms are required to provide

\footnotetext{
${ }^{11}$ European Council Regulation No. 1225/2009, Article 9, section 4.

${ }^{12}$ European Council Regulation No. 1225/2009, Article 2, section 12.

${ }^{13}$ European Council Regulation No. 1225/2009, Article 2, section 8.
} 
information including, for example, “...a complete description of the allegedly dumped product, information on prices at which the product in question is sold when destined for consumption in domestic markets...information on prices at which the product is sold...to a third country or information on the constructed value of the product... and information on export prices". ${ }^{14}$ This is the information needed to determine dumping margins. In addition, the petitioning firms must provide "information on changes in the volume of the allegedly dumped imports, the effect of those imports on prices of the like product on the community market, and the consequent impact of the imports on the community industry". ${ }^{15}$ This is the information needed to determine injury elimination margins. If petitioning firms are able to correctly anticipate when injury elimination margins are likely to be utilized in setting final duties, the earnings management incentives to exaggerate the extent of injury are particularly strong because in those cases the managed accounting data map directly into the magnitude of the ultimate duties imposed on exporting firms and the trade relief the petitioning firms receive. ${ }^{16}$ Our second hypothesis predicts that the earnings management by firms petitioning for trade relief in the EU is concentrated in firms initiating investigations in which tariffs are more likely to be based on injury elimination margins.

The European Commission, like other trade regulators, assesses injury at the industry level, not at the level of the individual firm. As such, there are free-rider and coordination problems among firms that belong to the allegedly affected industry in the EU. Individual firms have an incentive to be free-riders that do not manage earnings to help bolster the case that the industry has been injured. This allows these firms to avoid the potential costs associated with income decreasing earnings management to show injury while relying on other firms' accounting data to present a persuasive case in favor of an affirmative injury ruling. The potential costs of income decreasing earnings management stem from the uses of accounting data in capital markets and in contractual settings. As the number of firms associated with the petition for import relief increases, we expect that the incentives to be a free-rider, and the costs of coordinating earnings management activities across petitioners to avoid free-rider problems, increase. In addition, in cases with two or more sample petitioning firms, we expect the costs of coordinating earnings management activities and preventing free-rider problems to increase as the

\footnotetext{
${ }^{14}$ European Council Regulation No. 1225/2009, Article 5, section 2.

${ }^{15}$ European Council Regulation No. 1225/2009, Article 5, section 2.

${ }^{16}$ Interestingly, the international law firm of Holman, Fenwick, Willan, LLP, advertises a service that would assist clients in determining these two margins. As their webpage notes, "We regularly advise clients on the preparation of... antidumping questionnaire replies and perform dumping and injury margin simulations", quoted from: http://www.hfw.com/Anti-dumping.
} 
distance between the petitioners increases. This would result in diminished earnings management in those cases that have a greater number of sample firms joining together to petition for import relief and in cases in which the petitioning firms are more distant. Our third hypothesis predicts that the earnings management by firms petitioning for trade relief in the EU is concentrated in firms initiating investigations with fewer petitioning firms or with geographically closer petitioning firms.

The trade literature recognizes that potential retaliation can affect how countries impose tariffs in antidumping investigations. Blonigen and Bown (2003) find that U.S. decisions are more likely to be in favor of trade relief when the threat of retaliation (or more directly, the capacity to retaliate) of the foreign country is lower. Prusa and Skeath (2002) examine antidumping cases filed around the world in the 1980s and 1990s and find that a large number of cases are filed against countries that had previously initiated antidumping cases against the filing country. This effect was particularly pronounced for cases initiated against the jurisdictions with longestablished use of antidumping tariffs such as the EU, Australia, Canada and the United States. Nearly $90 \%$ of cases launched against those jurisdictions were initiated by countries with a retaliation motive. This suggests that petitioning firms located in countries that have high levels of exports to the countries accused of dumping products in their investigation will face a higher hurdle in order for their case to receive affirmative decisions that lead to trade remedies. This is true because the EU regulator will be more hesitant to impose trade sanctions against countries that import a significant amount of goods from the petitioning firms' host country(ies), and the petitioning firms' host country(ies) is less likely to lobby the European Council to impose tariffs when the threat of retaliation is high. ${ }^{17}$ Therefore petitioning firms located in countries that have a high level of exports to the countries accused of dumping goods in their petitions for trade relief may have heightened incentives to engage in income decreasing earnings management so that their injury appears more severe. Since there will be a bias against imposing tariffs in their investigation, a more severe level of injury will be necessary in order for the petitioner to justify trade relief. Our fourth hypothesis predicts that the earnings management by firms petitioning for trade relief in the EU is concentrated in firms initiating investigations against countries that receive high levels of imports from the petitioning firms' home countries.

\footnotetext{
${ }^{17}$ We thank Donal Byard for bringing this possibility to our attention. As we discuss earlier in this section, the interests of individual member states can influence the process leading to the imposition of tariffs at the stage of the vote by the European Council, if not before. 
Next we discuss cross-sectional predictions arising from factors associated with earnings management that are suggested by the prior literature. Our setting provides firms with predictable incentives to engage in income decreasing earnings management around the trade investigation initiation. For firms with a need for external financing, the capital market consequences of income decreasing earnings management could moderate the benefits the firm receives in the form of trade remedies. Accordingly, we predict that firms that raise either debt or equity capital during the Current time period face weaker incentives to engage in income decreasing earnings management. There is tension around this hypothesis, however, because it is possible that external capital providers could be aware of the incentives for earnings management in our setting and adjust financing terms accordingly, effectively eliminating any penalties for firms engaging in earnings management and seeking external financing. ${ }^{18}$ Our fifth hypothesis predicts that the earnings management by firms petitioning for trade relief in the EU is concentrated in firms that do not raise debt or equity capital around the trade investigation.

The past literature also provides mixed results about how country level regulatory institutions such as the rule of law, regulatory efficiency, and legal enforcement affect earnings management incentives. Leuz et al. (2003) document that legal enforcement is associated with reduced earnings management in broad samples of firms around the world. Burgstahler et al. (2006) find that better legal enforcement is associated with reduced earnings management in both public and private firms in the EU. In contrast, Ahmed, Neel and Wang (2013) also utilize very broad samples and find that IFRS adoption is associated with increased earnings management in countries with stronger country level institutions. Hence, the relation between country level institutions and earnings management incentives remains an open empirical issue. In addition, we examine income decreasing earnings management that is beneficial to stakeholders other than consumers, so it is not clear that results from the past literature will generalize to our setting. Accordingly, our sixth hypothesis is not directional and predicts that the earnings management by firms petitioning for trade relief in the EU differs between firms domiciled in countries with better regulatory institutions and legal enforcement and firms domiciled in countries with worse regulatory institutions and legal enforcement.

\footnotetext{
${ }^{18}$ Godsell (2016) provides evidence related to this point. For a sample of U.S. firms initiating antidumping investigations, he finds that the market does adjust the valuation of managed (and therefore less persistent) earnings, but only when firms file their second or subsequent petition. The market does not adjust the valuation of earnings for first-time petitioners, which dominate our sample.
} 


\section{Section 3 - Sample Selection and Descriptive Data}

We obtain data from the World Bank on 743 unique product-country investigations undertaken in the EU between 1980 and early 2012. ${ }^{19}$ There are around 1,000 domestic EU producers that are named as the potentially injured parties in these investigations, and the investigations examine whether dumping has been undertaken by nearly 2,000 foreign producers who export their goods to the EU. We begin our sample construction by matching the firms identified as petitioners in the World Bank database with the ORBIS database by Bureau van Dijk. The online version of ORBIS provides historical data for 10 years, and Bureau van Dijk provided us with a "snapshot" of the database as of 2002 to provide additional historical data from 1992-2002. All told, we have access to up to 21 years of historical data for public and private firms domiciled in the EU. ${ }^{20} \mathrm{We}$ use matching software provided by Bureau van Dijk to provide initial matches based on company names and then manually inspect the matching candidates to ensure that we are appropriately matching petitioning firms with ORBIS firms. We are able to identify 240 petitioning firms in the ORBIS database. Since some petitioning firms are involved as petitioners in more than one trade investigation, these 240 firms give rise to 285 firm-case events that are used in our subsequent empirical analysis. $^{21}$

Panel A of Table 1 shows the countries where we are able to identify petitioning firms. The sample covers 17 different jurisdictions in the EU with $22 \%$ of our sample in Italy, the home to the most petitioning firms in our sample. We find only two sample firms, or $1 \%$ of our total, in each of Lithuania, Slovenia and Slovakia. There are 20 or more firms identified in six countries, namely Belgium, Germany, Spain, France, the United Kingdom and Italy. Panel B of Table 1 shows the industry composition of our sample. Given that our sample is constructed from firms seeking trade remedies, it is not surprising that our sample is concentrated in industries that produce

\footnotetext{
${ }^{19}$ For the underlying data about antidumping investigations, and a description of the data, see Bown, Chad P. (2012) "Global Antidumping Database," available at http://econ.worldbank.org/ttbd/gad/

20 There are up to 21 years of data because the ORBIS database (both online and our "snapshot" of the database as of 2002) contains the most recent ten years of data for each firm. For example, the online version of the database we accessed contains 2003 to 2012 data for firms with 2012 data available and 2002 to 2011 data for firms that did not yet have updated 2012 data in the database. This also applies to the "snapshot" data we received as of 2002. As such, the full database spans up to 21 years from 1992-2012. We initially planned to acquire our data from Amadeus, another Bureau van Dijk database covering the EU in particular. ORBIS is a broader database with international coverage. We did not use Amadeus to acquire financial statement data for our sample firms because we discovered that Amadeus does not contain data for dead firms. Because Amadeus only contains data for surviving firms, it is subject to potential survivorship bias.

${ }^{21}$ A few of these firm-case events that fall very early or very late in our sample period do not have data available for all the event years we examine. Nevertheless, we utilize the available data for these firm-case events. We also hoped to use the EU setting to examine the earnings management activities of private versus public firms (Ball and Shivakumar (2005) and Burgstahler et al. (2006)) and to examine the effects of IFRS adoption on the earnings management activities of public firms. Unfortunately the small number of public sample firm observations (40) precluded an examination of either of these issues.
} 
tradable goods. The sample is dominated by manufacturing, durable and non-durable goods companies. Finally, Panel C shows the time periods when trade investigations are initiated by sample firms. There is no evidence of strong clustering in time or obvious time trends in the sample observations, though there is some indication of reduced trade investigation initiations during the post-crisis years of 2008, 2010 and 2011. The number of observations in 2011 also reflects the fact that some of the 2011 investigations were not completed at the time of our data collection.

We supplement our sample of trade petitioning firms with a matched sample of similar firms to provide more non-event observations to estimate model parameters. While many studies of discretionary accruals form estimation samples based on similar industry composition, this approach is not appropriate in our setting. While petitioning firms in the industry may have the strongest incentives to engage in earnings management because they know the petition will be filed, it is conceivable that non-petitioning members of the industry could also be engaging in earnings management around the initiation of the petition. This is a reasonable expectation because the European Commission also considers industry data to assess injury, not just the data of the petitioning firms. Indeed, in Jones (1991) investigation of earnings management during trade investigations in the United States, she examines 23 firms, only 14 of which are named as petitioners. While she does find that earnings management appears more pronounced in petitioning firms, there is also some evidence of earnings management by nonpetitioning firms in the affected industry. We follow the advice of Ecker, Francis, Olsson and Schipper (2013) and create a matched sample based on firm size rather than industry. ${ }^{22}$ In addition to matching on firm size, we also include a performance-based match in which we select firms that are close to our sample firms in Return on Assets (ROA) in the event year. We further follow Gonzalez, Schmid and Yermack (2013) and identify five matching firms for each sample firm to form our estimation sample. These matching firms are drawn from the population of firms in the same country as the petitioning firm, and we also restrict this matching algorithm to match only public firms to public petitioning firms and only private firms to private petitioning firms. Specifically, we identify potential matching firms that meet the above two restrictions that have an ROA within 0.1 of the

${ }^{22}$ They report that estimation samples based on similarity in size "perform at least as well as estimation samples based on industry membership in detecting discretionary accruals", while permitting less sample attrition than industry-based matches (Ecker et al., 2013, p. 190). 
sample firm during the event year. ${ }^{23}$ From that subset of firms, we select the five firms that are closest to the sample firm in lagged total assets. This provides a substantial increase in the estimation sample while imposing a restriction that should ensure that petitioning firms and matched firms are relatively similar in size, performance, country and legal form. ${ }^{24}$

Panel A of Table 2 provides descriptive data on the sample of petitioning firms, the matched firms, and the combined sample. Consistent with the prior literature, total accruals are on average negative with a central tendency around -3.5 to -4.0 percent of lagged total assets. As Panel A reveals, our matching algorithm is successful in identifying a set of matching firms very similar in total assets, cash flows and accruals to the sample of petitioning firms. Panel B of Table 2 shows the time-series pattern of total accruals, working capital accruals and operating cash flow around the trade investigation initiation date. The time-series of both total and working capital accruals reveal lower total and working capital accruals in year $t+1$, and operating cash flows appear lower than normal in years $t-1$ and $t$. Panel $\mathrm{C}$ of Table 2 shows the sample composition across the primary sample-wide cross-sectional partitioning variables that we utilize in testing hypotheses two through six. These data indicate that our sample partitions provide relatively independent sorts of sample firms except not surprisingly our partitions based on different measures of legal enforcement and regulatory quality do produce overlapping sorts of the data. ${ }^{25}$

\section{Section 4-Research Design}

Accounting earnings consists of two components, actual cash flows during the period and a variety of accounting accruals that are intended to account for events that affect economic performance in the current period but do not result in cash flows in the current period. Examples of these accruals are treating the costs of producing inventory as an asset until the goods are sold, even though the cash is spent when the goods are manufactured,

\footnotetext{
${ }^{23}$ Results are qualitatively similar if we match on size but do not match on ROA.

${ }^{24}$ We perform this matching with replacement, so that one matched firm can be assigned to more than one sample firm. We do this so that when we later partition our sample each sample firm has the best set of five matching firms. In the full sample, this means that there are fewer matched firms than would be implied by taking the number of sample firms and multiplying by five. Consequently, most of our samples that are partitioned in subsequent analysis have a total number of observations that exceed the total number of observations in the full sample as the data for a single matched firm may be used in both subsamples generated by any given sample partition.

${ }^{25}$ To further ensure that the cross-sectional tests we perform identify unique factors associated with the incentives for earnings management in our setting, we included interactions between indicator variables for each of our partitioning variables and our event time indicators in a single model. We used only the time varying regulatory quality measure as the institutional quality variable in that model. The coefficients on these interaction terms were negative and significant except those involving regulatory quality and \# of petitioners $<=2$. Further testing revealed that if we drop the interaction involving proximate petitioners then the interaction with \# of petitioners <=2 becomes significantly negative. This again suggests that our cross-sectional tests are relatively independent but does suggest that our coordination related variables are less so. These results are reported in the online appendix.
} 
and recording both receivables and payables that result from selling or purchasing goods on trade credit. We focus on the accrual component of earnings as this component involves estimates and is therefore subject to manipulation. ${ }^{26}$ Our setting allows for identification of the period(s) when firms have incentive to manage their accounting earnings. We first perform a systematic review of the preliminary investigation decision documents and find that the injury determination decision in the EU generally involves a comparison of accounting and other data over a four year period, though in a few cases a somewhat longer or shorter total investigation period for injury determination is employed. In the vast majority of cases, this period ends within the two year period centered on the date the investigation is initiated. In other words, the four year injury investigation period typically ends sometime between one year before and one year after the investigation is initiated. Further, injury is quite consistently determined based on whether there is a decline in the petitioning industry's financial performance between the beginning of the four year period and the end of the four year period. In the typical case there is an affirmative decision about injury because of a decline in financial performance between the first two years of the injury investigation period and the final two years of the injury investigation period. The upshot of this discussion is that the injury investigation process provides clear incentives for firms to engage in income decreasing earnings management in the year that the trade investigation is initiated and the following year. If the petitioning firms have sufficient foresight to know that they will launch a trade investigation in the future, the process also provides incentives to engage in income increasing earnings management in the two or three years preceding the launch of the investigation. Our empirical specification allows for this possibility, though we do not predict this latter form of earnings management because it is not clear that firms would have this much foresight about future investigation initiations.

Our model is an expanded version of the Jones (1991) model. Following McNichols (2002), we incorporate the lead, lag and contemporaneous cash flow terms suggested by Dechow and Dichev (2002). We also incorporate other time varying firm characteristics suggested by the past literature. Our design also captures

\footnotetext{
${ }^{26}$ The incentives in this setting do not clearly translate into real earnings management predictions. Consider real earnings management through over or under production, for example. If petitioning firms under produce, for example, this would increase cash flows, decrease earnings, and decrease inventories. The increase in cash flows and decrease in inventory would be damaging to their injury case, while the decrease in earnings would be beneficial. Hence while we think the setting provides clear and compelling accrual management incentives, the incentives for real earnings management are less clear. Nevertheless, we conducted an additional test to examine this possibility that we describe in footnote 28 .
} 
additional modifications suggested by Dechow et al. (2012) as we incorporate indicator variables for time periods that correspond to periods that could contain both initial earnings management and the reversal of earnings management. Our expanded modification is slightly more complex than theirs in that they incorporate only two time periods, the period of the earnings management and the reversal period, while we include separate yearly indicator variables for a seven year period around the investigation. ${ }^{27}$ This base model has a long history of use to detect accrual manipulation in the accounting literature, and Dechow et al. (2012) provide extensive evidence related to the performance of the model. Our setting provides us with reasonable priors about the timing and direction of the earnings management, which should improve the power of our tests to detect earnings management. To control for firm characteristics that may also affect firms' accruals choices, we include proxies for firm size, leverage, growth, operating volatility and net operating assets (Burgstahler et al. 2006; Barton and Simko, 2002). Finally, to further mitigate the concern that the decline in accruals simply reflects poor performance resulting from dumping rather than earnings management, we include the median contemporaneous stock return for all public firms in the corresponding Fama-French 30 industry from the country that is home to the petitioning firm. We do not proceed in two stages, with a first stage identifying discretionary accruals and a second stage explaining variation in discretionary accruals. Chen, Hribar and Melissa (2016) report that using two-step regression procedures when there are correlations between explanatory variables can result in biased coefficient estimates and standard errors, leading to type 1 and type 2 errors. They suggest single-step procedures as the most basic solution to this problem. Specifically, we initially estimate the following equation:

$$
\begin{aligned}
& \text { WC_ACC } C_{i, t} \text { orTOT_ACC } C_{i, t}=\alpha_{0}+\beta_{0} 1 / \text { TotAssets }_{i, t-1}+\beta_{1} P P E_{i, t}+\beta_{2}\left(\Delta R E V_{i, t}-\Delta A R_{i, t}\right)+\beta_{3} C F O_{i, t} \\
& +\beta_{4} \mathrm{CFO}_{i, t-1}+\beta_{5} \mathrm{CFO}_{i, t+1}+\beta_{6} \text { Event Year } t-3_{i, t}+\beta_{7} \text { Event Year } t-2_{i, t}+\beta_{8} \text { Event Year } t-1_{i, t}+\beta_{9} \\
& \text { Event Year } \text { Ye }_{i, t}+\beta_{10} \text { Event Year } t+1_{i, t}+\beta_{11} \text { Event Year } t+2_{i, t}+\beta_{12} \text { Event Year } t+3_{i, t}+\beta_{13} \text { Event Firm }
\end{aligned}
$$

\footnotetext{
${ }^{27}$ Occasionally, there are two petitions involving the same firm that are close enough in time that a single fiscal year for that firm could fall somewhere in the expanded event period for more than one case. When that occurs we let the earlier event determine the event period coding for all fiscal years up to the fiscal year in which the subsequent petition is filed, at which time the event coding is determined by the subsequent event. For example, consider a firm with petitions filed in early 2005 and early 2008 with a December 31 fiscal year end. The December 31, 2004 fiscal year is coded as the event year (zero) for the 2005 case, and the 2005 and 2006 fiscal years are coded as event years +1 and +2 , respectively. The 2007 fiscal year is coded as an event year (zero) due to the subsequent case filed in 2008 , and this year is not coded as an event year +3 based on the 2005 case. In this way each fiscal year is identified with only one event period indicator variable, and the coding presumes that the incentives related to the subsequent case dominate beginning with the year when that case is filed. We use an analogous procedure to code the condensed event indicators in equation (2). If we change this procedure and allow a single fiscal year to be coded as one for more than one event period indicator there is no change in our inferences.
} 


$$
\begin{aligned}
& \text { Indicator }_{i}+\beta_{14} \text { Size }_{i, t}+\beta_{15} \text { Leverage }_{i, t}+\beta_{16} \text { Growth }_{i, t}+\beta_{17} \text { Std }(\text { Sales })_{i, t}+\beta_{18} N O A_{i, t-1}+\beta_{19} \text { Return }_{i, t} \\
& + \text { Country Fixed Effects }+ \text { Industry Fixed Effects }+ \text { Year Fixed Effects }+\varepsilon_{i, t}
\end{aligned}
$$

All continuous variables are scaled by TotAssets $_{i, t-1}$, which is lagged total assets. WC_ACC is working capital accruals, defined as the change in current assets minus the change in current liabilities minus the change in cash plus the change in short-term debt. TOT_ACC is total accruals, defined as WC_ACC minus depreciation. Event Year is the fiscal year that ends closest to the date on which the European Commission initiates its investigation. $\triangle R E V$ is the change in sales revenue and $\triangle A R$ is the change in accounts receivable. $P P E$ is net property, plant and equipment. $C F O$ is cash flow from operations. Size is the natural logarithm of total sales revenue. Leverage is book leverage, defined as long-term debt plus the current portion of long-term debt, scaled by total assets. Growth is sales growth, defined as sales growth from $t-1$ to $t$. Std(sales) is operating volatility, defined as the standard deviation of sales over the past three years, i.e., $t, t-1, t-2 . N O A$ is net operating assets, calculated as the sum of shareholders equity and interest-bearing debt, minus cash assets, scaled by sales. Return is the median contemporaneous annual excess stock return (annual raw return minus the market index return) for all public firms that are from the same Fama-French 30 industry from the country that is home to the petitioning firm. We extract return data from Worldscope. We cluster standard errors by firm and year.

As mentioned earlier, we also estimate a collapsed version of this model in which we replace the individual year indicator variables with variables that capture average earnings management during a pre-injury period consisting of event years $t-3, t-2$ and $t-1$ (Pre), a current injury period indicator variable measuring average earnings management during the injury determination years $t$ and $t+1$ (Current), and a post injury determination indicator variable measuring average earnings management during periods $t+2$ and $t+3$ (Post):

$$
\begin{aligned}
& \text { WC_ACC } C_{i, t} \text { orTOT_ACC } C_{i, t}=\alpha_{0}+\beta_{0} \text { I/TotAssets } i_{i, t-1}+\beta_{1} \text { PPE }_{i, t}+\beta_{2}\left(\Delta R E V_{i, t}-\triangle A R_{i, t}\right)+\beta_{3} C F O_{i, t} \\
& +\beta_{4} \text { CFO }_{i, t-1}+\beta_{5} \text { CFO }_{i, t+1}+\beta_{6} \text { Pre }_{i, t}+\beta_{7} \text { Current }_{i, t}+\beta_{8} \text { Post }_{i, t}+\beta_{9} \text { Event Firm Indicator }_{i}+\beta_{10} \\
& \text { Size }_{i, t}+\beta_{11} \text { Leverage }_{i, t}+\beta_{12} \text { Growth }_{i, t}+\beta_{13} \text { Std }(\text { Sales })_{i, t}+\beta_{14} \text { NOA }_{i, t-1}+\beta_{15} \text { Return }_{i, t}+\text { Country Fixed } \\
& \text { Effects }+ \text { Industry Fixed Effects }+ \text { Year Fixed Effects }+\varepsilon_{i, t}
\end{aligned}
$$

All other variables are defined as in equation (1).

Based on the past literature, we expect accruals to be positively related to cash sales growth, lead and lagged cash flow, and negatively related to current period cash flows. Since fixed assets generate depreciation 
charges, $P P E$ is expected to be negatively related to TOT_ACC. We include an event firm indicator variable to capture any systematic differences in accruals between petitioning firms and matching firms outside the event window. We include country and industry fixed effects to capture any systematic differences in accruals across EU countries or industries represented in our sample. We include year fixed effects to capture any sample-wide shifts in accruals through the changing economic conditions that characterize our sample period. Our primary empirical predictions are that discretionary accruals will be significantly negative during the Current time period in the collapsed specification, or the individual year indicator variables for the years that fall in the Current period in the expanded specification, and that these coefficients will vary across firms or over time as discussed in our hypotheses. Specifically, our primary empirical prediction is that one or both of $\beta_{9}$, and/or $\beta_{10}$ in equation (1) will be negative and that $\beta_{7}$ will be negative in equation (2). As discussed above, it is also conceivable that the data may reveal significantly positive abnormal accruals for the Pre and Post indicators in the collapsed specification, or the individual year indicator variables for the years that fall in the pre or post period in the expanded specification, consistent with either income increasing earnings management prior to the initiation of the trade investigation to maximize the apparent injury attributed to dumping or for other reasons, or with the reversal of the income decreasing accruals occurring after the Current period.

\section{Section 5 - Empirical Analyses}

\section{Section 5.1 Main Results}

Table 3 provides the results of estimating equations (1) and (2) on the full sample of petitioning firms and the matched firms as described in Section 3. We begin with a discussion of the results from the expanded specification detailed in equation (1), which are reported in columns (1) and (2). Consistent with H1, both total accruals and working capital accruals are significantly negative in both the event year and event year +1 . The magnitude of these discretionary accruals is also economically significant, with discretionary accruals lowering reported return on assets more than $1 \%$ in the event year and year +1 . There is also some evidence of positive abnormal accruals in the years preceding the initiation of the investigation as event year -2 exhibits significantly positive discretionary total accruals. The other coefficients for years $-3,-2$ and -1 are positive but not significant at conventional levels. Given the pattern of discretionary accruals that we observe between event years -3 and +1 (positive but generally insignificant in years $-3,-2$ and -1 , and negative and significant in years 0 and +1 ), it is not 
surprising that we do not observe discretionary accruals reversals during event years +2 and +3 . The control variables in the model have predicted signs and are largely consistent with the prior literature. Specifically, accruals are positively related to cash sales growth, lead and lag cash flows, and negatively related to current period cash flows. Property, plant and equipment gives rise to depreciation expense and is therefore negatively related to total accruals. The event firm indicator variable is insignificant in both regressions, indicating that our event firms' accruals do not differ from the matched sample outside the event window. Accruals increase with firm size and growth and decrease with leverage, operating volatility and net operating assets. Accruals are generally unrelated to industry-wide contemporaneous returns.

Columns (3) and (4) provide the results of the collapsed specification detailed in equation (2). The results from the collapsed specification are consistent with the results from the expanded specification. Total accruals and working capital accruals are positive but insignificantly different from zero during the Pre period. Both total accruals and working capital accruals are significantly negative during the Current time period, and both types of accruals are not different from zero during the Post period. The coefficients on the other variables in the model are predictably very similar in the expanded and collapsed specifications. Given the consistency of the results, we report all subsequent results using the simplified collapsed specification. We have also reproduced all of our analyses using the expanded specification and the primary inferences from the analysis are unaffected. ${ }^{28}$

We also ran an expanded specification in which we interacted our event dummy variables (either just Current or all of Pre, Current and Post) with each of the three cash flow terms in the model. This allows for the possibility that cash flows are unusual during these periods due to actual injury or for other reasons, and that this creates an unusual relationship between cash flow and accruals during our event period. Some of the event period indicators interacted with lagged cash flows have positive coefficients but our inferences are not affected by this expansion of the model. We also created similar interaction terms between our event indicator variables and $\triangle R E V-\triangle A R$, and between our event indicator variables and RETURN. The RETURN interactions are all insignificant, but there is evidence that accruals show heightened sensitivity to cash revenue shocks during our

\footnotetext{
${ }^{28}$ The ORBIS data we use in this investigation in the EU provides too little income statement detail to estimate models of real earnings management except for the abnormal cash flow model from Roychowdhury (2006). That test shows no evidence of real earnings management.
} 
event periods. Our main result of negative abnormal accruals during the Current time period is unaffected (actually slightly stronger) by this change in specification.

We also create two alternative matched samples in which we match on $\triangle \mathrm{ROA}$ rather than ROA. The first alternative sample is created using matching firms with $\triangle \mathrm{ROA}$ within 0.05 of the sample firms and the second is created using matching firms with $\triangle \mathrm{ROA}$ within 0.025 . This provides a sample of matched firms that are experiencing a similar shock to performance rather than a similar level of performance. Our primary inferences are unchanged with these alternative matched samples.

To ensure that our sample firms respond similarly to our control firms to economic shocks, we create pseudo-events based on the years with the largest positive and largest negative GDP change, or based just on the years with the largest negative GDP change to capture negative events. We repeat our tests using these pseudoevents and find that all event indicator variables are insignificant, suggesting that the accruals of our treatment firms and control firms respond similarly to economic shocks. These additional tests enhance confidence that our tests are identifying earnings management rather than actual economic injury resulting from dumping. The results from these tests are tabulated and reported in the online appendix.

While our primary specification includes an event firm indicator variable to capture any systematic differences in accruals between petitioning firms and control firms, this specification does not allow for firm specific differences in accrual behavior across petitioning firms. To ensure that our results are not affected by this restriction, columns (5) through (8) of Table 3 show our main results when we replace the industry and country fixed effects and the event firm indicator variable with firm fixed effects. Columns (5) and (6) show the results of our expanded specification and columns (7) and (8) show the results of our collapsed specification. The results from this specification are similar to the main results reported in columns (1)-(4). Not surprisingly model $R^{2} s$ are somewhat higher with firm fixed effects. ${ }^{29}$

Section 5.2 Cross-sectional tests based on setting specific economic factors

${ }^{29}$ This specification is arguably closer to the specification utilized by Jones (1991) who estimates regressions on firm by firm basis. Jones (1991) has a median of 28 (minimum of 14) years prior to her event years to estimate model parameters for each firm. We have a maximum of 20 and an average of about 9 years of data per firm, including event periods and periods after the event year. This precludes firm level estimation for our sample. 
After establishing sample-wide evidence consistent with earnings management, we next examine a number of case specific factors that we predict will create cross-sectional variation in the incentives for earnings management in our setting. Our first sample partition is based on case-level variation in how the duties (if any) applied in the case are determined. As we discussed earlier, a higher percentage of injury elimination margins used in the case increases earnings management incentives because injury elimination margins are a function of injury and are determined by petitioning firms' accounting data. Since the assignment of injury elimination margins versus dumping margins as the final duty amount varies by exporting firm and is not uniformly applied at the case level, we initially partition our sample using the median percentage of exporters assessed injury elimination margins versus dumping margins. In particular, cases in which more than $33 \%$ (the median) of the duties assigned are based on injury elimination margins are considered high use of injury elimination margin cases, and cases in which $33 \%$ or less of the duties are based on injury elimination margins are considered low use of injury elimination margin cases. ${ }^{30}$ Our prediction is that earnings management around the trade investigation will be concentrated in the high use of injury elimination margin sample. As discussed earlier, this test helps provide confidence that our tests are capturing earnings management in response to the incentives present in our setting because this test directly varies the strength of those incentives.

Our results of estimating equation (2) for this partition are presented in Table 4 . In Table 4 and all subsequent tables, we include the firm characteristics as controls but do not report their coefficients to conserve space. The online appendix provides tables that include the coefficients on firm control variables. Columns (1) and (2) report the results for the low use of injury elimination margin sample and columns (3) and (4) report the results for the high use of injury elimination margin sample. The coefficients on the Current period indicator are insignificantly different from zero in the low use of injury elimination duty sample in columns (1) and (2) but these coefficients are negative and economically and statistically significant in the high use of injury elimination margin sample in columns (3) and (4). Tests of differences in coefficients reveal that the coefficients on the Current time period are significantly more negative in the sample with high use of injury elimination margins.

\footnotetext{
${ }^{30}$ Ideally, we would base this partition on the proportion of the volume of exports into the EU that are assigned injury elimination margins, not the proportion of exporting firms. Unfortunately this information is not available to us. We explore the sensitivity of our results to this $33 \%$ threshold later.
} 
This is consistent with the prediction in our second hypothesis that higher use of injury elimination margins provides enhanced incentives for earnings management. Given the cost-benefit tradeoff that would have to accompany any decision to engage in earnings management, it appears that sample firms are rationally anticipating when the benefits of earnings management will be greater and responding accordingly. ${ }^{31}$

It is also possible that actual injury is more severe in cases with more use of injury elimination margins. On the one hand this is possible because these cases have relatively high dumping margins. On the other hand, injury elimination margins are used only when they are lower than dumping margins, which suggests that this partition does not necessarily identify the most injured firms. We also note that the Pre coefficients and the coefficients on the cash flow and return variables appear quite consistent across the panels. This does not appear consistent with this sample partition identifying firms with more or less actual injury.

To examine the sensitivity of our choice of the median percentage of exporters assessed the injury-based duty as the point distinguishing high and low use of injury elimination margins, we experiment with other choices of benchmarks. Specifically, we examine two alternative definitions of high use of injury elimination margins. First we classify as high use any investigation in which there is at least one injury elimination margin assigned. Second, we classify as high use any investigation in which half or more of the margins are based on injury. If our conjecture that greater use of injury elimination margins enhances the incentives to engage in earnings management, then earnings management should increase as we move from at least one, to the median (1/3), to $1 / 2$ injury elimination margins. Table 5 displays the results for the high use of injury elimination margins sample for each of the three alternative definitions. This table reveals that each of these samples is associated with statistically and economically significant earnings management evidenced by the coefficients on the Current period indicator, and importantly, the evidence of earnings management increases along with the threshold for assigning firms to the high use of injury elimination margins sample. This is the pattern we would expect to observe if firms had accurate ex ante assessments of the ex post observed use of injury elimination margins and the use of those margins created greater incentives for earnings management.

\footnotetext{
${ }^{31}$ As discussed in more detail in footnote number 24, the total observations reported across the two subsamples in Table 4 exceeds the total observations reported in the full sample in Table 3 because of how we implement the matching algorithm to produce the matched sample.
} 
Next we examine the effect of the number of sample firms named in the petition for import relief on earnings management. ${ }^{32}$ Since antidumping investigations are initiated on behalf of an entire EU industry, there are free-rider and coordination problems that arise when there are multiple firms in the EU industry. In fact, Feinberg and Hirsch (1989) find that U.S. industries with more firms are less likely to petition for import relief, which is consistent with the idea that coordination costs and free-rider problems are more severe in industries with more firms. When there are more sample firms named on the petition, we expect that it is more difficult to control free-rider problems and that the costs of attempting to coordinate earnings management activities across firms increase. As a result, firms involved in these petitions are less likely to engage in earnings management to increase the apparent injury suffered by the EU industry because each individual firm is less sure that other firms in the industry will do likewise. Since the median case in our sample has two sample firms named in the petition, we partition the sample based on cases with one or two sample petitioning firms and cases with more than two sample petitioning firms.

The results of this analysis are reported in Table 6. Columns (1) and (2) report the results for the sample cases with more than two petitioning firms and columns (3) and (4) report the results for the sample cases with one or two petitioning firms. The coefficients on the Current time period are negative and significant when there are one or two petitioning firms, but are not significantly different from zero when there are more than two petitioning firms. Tests of differences in coefficients reveal that the coefficients on the Current time period are significantly more negative in the sample with only one or two petitioners for both total accruals and working capital accruals. These results are generally consistent with our third hypothesis.

We also conduct a test that examines geographic distance as another potential factor affecting coordination costs and free-rider problems. We measure distance as the sum of the distances between all sample petitioners in the case. Table 7 presents results when we partition the sample of investigations with two or more petitioners

\footnotetext{
${ }^{32}$ We base this analysis on the number of sample firms initiating the petition rather than on the number of firms named in the original petition because in some cases industry associations rather than individual firms initiate petitions. It is sometimes, but not always, possible to distinguish trade associations from firms among the entities named as petitioning parties in the petition, so it is not possible to construct an accurate list of the total number of petitioning firms for each petition. When we partition our sample based on the median number of petitioning entities (without distinguishing between trade associations and firms, and including all petitioning entities, not just those in our sample), we continue to find that the Current period indicator only has a significantly negative coefficient in the low number of petitioners sample. However, the $p$-value for the test of differences in the Current period coefficient between the low and high number of petitioners samples is between 0.10 and 0.20 in these tests.
} 
based on the median aggregate distance between all sample petitioners (1,500 kilometers). The above median distant sample is labeled the "Distant" sample and is reported in columns (1) and (2) of Table 7. The below median distance sample is labeled the "Proximate" sample and is reported in columns (3) and (4) of Table 7. As the table shows, earnings management is concentrated in those cases in which the petitioners are geographically proximate, consistent with idea that geographic distance impedes coordination. Tests of differences in coefficients reveal that the coefficients on the Current time period are significantly more negative in the proximate sample. ${ }^{33}$

Our next sample partition examines the effect of trade retaliation on earnings management incentives in our setting. To do this we investigate petitioner country exports to the foreign country allegedly dumping goods into the EU. As discussed earlier, the trade literature identifies the capability to retaliate as a factor that moderates regulator incentives to assign duties in antidumping investigations. Capacity to retaliate is a direct function of the extent to which the country(ies) accused of dumping goods into the EU imports goods from the country alleging dumping. When the country that is home to petitioning firms has a high level of exports to the country(ies) accused of dumping goods into the EU, regulators in the country that is home to the petitioning firms may be reluctant to lobby Brussels to award trade relief in the case. Regulator reluctance to assign duties when the threat of retaliation is high may incent petitioning firms to provide more persuasive evidence of economic injury by engaging in more earnings management. To the extent that the petitioning firms think it is necessary to bolster their claim of injury in order to make it more difficult for the regulator to deny relief in the case, we expect to observe more earnings management in the sample of firms that are domiciled in countries with high levels of exports to the countries accused of dumping in the firm's petition.

To implement this test, we first calculate the total exports from the country that is home to each petitioning firm in our sample during event year 0 for that firm. We then calculate the proportion of these total exports that go to each country named in the petition as a country allegedly dumping goods in the EU. If there is more than one country named in the petition as a country allegedly dumping goods in the EU, we sum the proportion of

\footnotetext{
${ }^{33}$ We thank an anonymous reviewer for this suggestion. We also repeated this test using the average distance between petitioners and find similar results. That specification helps to ensure that our aggregate distance measure is not just mechanically increasing in the number of petitioners and essentially replicating our earlier results based on number of petitioners. We also considered examining separately cases in which there are two or more petitioners from the same country versus those cases in which there are two or more petitioners from different countries. Unfortunately, the sample in which there are two or more petitioners from the same country was too small for analysis (fewer than 20 observations).
} 
exports going to all such countries to create a measure of the cumulative retaliation capability of the defendant countries. Finally, we partition our sample into high and low exports to defendant countries based on the median value of this sum (which is about $1 \%$ ). The low exports to defendant countries sample firms face low capacity to retaliate and the results for this sample partition are reported in columns (1) and (2) of Table 8. The high exports to defendant countries sample firms face high capacity to retaliate and the results for this sample partition are reported in columns (3) and (4) of Table 8.

The Current period coefficients are negative and economically and statistically significant in the high capacity to retaliate sample but not significantly different from zero in the low capacity to retaliate sample. Tests of differences in coefficients reveal that the coefficients on the Current time period indicator are significantly more negative in the high capacity to retaliate sample for both total accruals and working capital accruals. These results are consistent with our fourth hypothesis that retaliation threats affect earnings management incentives.

\section{Section 5.3 Cross-sectional tests based on factors affecting earnings management identified in prior literature}

We next estimate equation (2) when the sample is partitioned into firms that raise new financing versus firms that do not raise new financing over the two-year period denoted by Current. We calculate the difference between long-term debt in event year +1 and long-term debt in event year $-1 .{ }^{34}$ Following Naranjo, Saavedra and Verdi (2015), we designate firms that experience an increase in long-term debt of more than five percent of beginning of period total assets as debt issuing firms. Similarly, we calculate ending shareholders' equity in event year +1 minus the sum of (ending shareholders' equity in event year $-1+$ net income in event year $0+$ net income in event year +1 ) to measure equity issuance. We designate firms with a change in equity greater than five percent of beginning of period total assets as firms with new equity issuance. ${ }^{35}$ If the firm is classified as either a new debt

\footnotetext{
${ }^{34}$ The ORBIS database contains very limited financial statement data compared to more familiar international databases that focus on public companies (e.g., Compustat Global; Worldscope). ORBIS also contains no direct information about firms' financing activities that would allow us to determine which firms raise additional debt or equity capital in any given year. As a result, we have to use the limited financial statement data available in ORBIS to develop an approximation to classify firms into those that raise new financing during event years 0 and +1 and those that do not.

${ }^{35} \mathrm{We}$ acknowledge that our equity financing approximation contains potentially more errors as the ORBIS database does not provide data on dividends. We rely on the clean surplus relation to determine which firms are likely to issue new equity financing in event years 0 to +1 . Since dividends can only be greater than or equal to zero, an error in this approximation would occur for firms who issue new equity that is smaller in amount than the dividends they pay plus five percent of total assets.
} 
or new equity financing firm, the firm is included in the new financing sample, otherwise the firm is included in the no new financing sample. ${ }^{36}$

Table 9 provides the results of estimating equation (2) on the sub-samples partitioned based on new financing. As columns (3) and (4) of Table 9 show, the negative discretionary accruals in the Current time period are economically large and statistically significant for those sample firms that do not raise new financing in these two years. The discretionary accruals in the Current time period are not statistically significant for the firms raising new financing reported in columns (1) and (2). Tests of differences in coefficients reveal that both total accruals and working capital accruals are significantly more negative in the Current time period in the without new financing sample, though this test of differences is marginal with $p$-value $=0.10$ for total accruals. ${ }^{37}$ In summary, our results in Table 9 provide some evidence that income decreasing earnings management in the Current time period is concentrated in firms without external financing needs, consistent with our fifth hypothesis.

Table 10 reports the results of estimating equation (2) when we partition the sample based on two measures that the past literature suggests could affect the enforcement of accounting standards. First, we utilize a static legal enforcement measure calculated as the average of Rule of Law and Judicial Impartiality based on La Porta, Lopez-de-Silanes, Shleifer and Vishny (2002). Burgstahler et al. (2006) predict and find that similar measures of legal enforcement are associated with earnings management in both public and private firms in the EU, so these measures are appropriate for our sample that contains a mixture of public and private firms. We split our sample into weak and strong legal enforcement based on the median value of this measure. These results are reported in columns (1)-(4) of Table 10. The Current period coefficients are negative and statistically and economically significant for firms domiciled in countries with both low and high levels of legal enforcement. The test for equality of the Current period coefficients across these two subsamples fails to reject the null of equality for both total accruals and working capital accruals.

\footnotetext{
${ }^{36}$ It is possible that these approximations identify firms as new financing firms when there are small increases in long-term debt or shareholders' equity due to transactions other than new financings, such as interest accretion or stock option grants. We believe that any coding errors like this would work against finding results for this partition. For this reason we specify the five percent of total asset threshold in an attempt to remove firms with small increases in long-term debt or shareholders' equity that are unrelated to raising financing from our new financing sample. We also used a ten percent of total assets threshold and obtain similar results.

${ }^{37} \mathrm{We}$ also repeated all of our analyses clustering standard errors by case or investigation rather than by firm. The only inference affected at all by that change is that the $p$-value on the difference in total accruals between financing and no financing firms increased from 0.10 to 0.14 .
} 
Our second institutional quality measure is a time-varying measure of regulatory quality compiled and discussed in Kaufmann, Kraay and Mastruzzi (2009) and applied in Christensen, Hail and Leuz (2013). This measure "reflects perceptions of the ability of the government to formulate and implement sound policies and regulations that permit and promote private sector development" (Kaufmann et al., 2009, p. 6). This variable is measured every other year beginning in 1996 until 2002, and then is measured annually after 2002. When the variable is measured every other year, we construct a measure for the missing years by averaging the measure in the two years that are adjacent to the missing year. We partition the sample into a low regulatory quality subsample and high regulatory quality subsample based on the median country-year measure of regulatory quality. The results for this partition are reported in columns (5)-(8) of Table 10. These results are very similar to the results based on the legal enforcement partition, and again suggest that earnings management in our sample firms does not differ across countries with differing institutional quality. Lack of power does not appear to be affecting this null result as the coefficients of interest are generally significant in each sample.

Because this null result for our sixth hypothesis conflicts with some prior literature, we conducted an additional test using another set of time-varying measures of regulation and enforcement affecting financial reporting. Specifically, we collected the AUDIT, ENFORCE, and TOTAL scores from Brown, Preiato and Tarca (2014). These measures are available for 2002, 2005 and 2008. We apply the 2002 data to all of our sample years before 2002 and up to and including 2002, use the 2005 score and then interpolate to fill in scores for each year between 2003 and 2007, and apply the 2008 scores to 2008 and all years after 2008. We believe these scores are a good fit for our setting because they measure a number of features of the audit environment across countries (AUDIT) and also focus on regulatory enforcement directly related to financial statements (ENFORCE). In addition, there is at least some time series variation in these measures, and the measurement dates were chosen to capture a period when enforcement was changing in many countries, particularly in the EU. We create sample partitions based on the median score for AUDIT, ENFORCE, and TOTAL (which combines AUDIT and ENFORCE). These results are presented in Table 11. As that table clearly shows, we continue to find no significant differences between high and low score countries for any of these measures. ${ }^{38}$

\footnotetext{
${ }^{38}$ Note that all three of the regulatory sample partitions are based on either the country (legal enforcement) or the country-year (regulatory quality, AUDIT, ENFORCE and TOTAL) median, not the median value for sample firm-years. As a result these partitions are not balanced 
On the surface, these results are inconsistent with some past literature utilizing broad samples of public firms (e.g., Leuz et al., 2003) or samples of public and private firms in the EU (Burgstahler et al., 2006) that suggest that better legal and regulatory institutions help curb earnings management. There are at least three possible reasons why we may be finding that regulatory institutions do not appear to affect earnings management in our setting while the past literature finds that these institutions do matter. The past literature generally examines broad samples of firms in which the earnings management incentives are not specified or clear. We suspect that in these samples of firms, most earnings management activities involve income increasing earnings management undertaken due to capital market incentives. This type of earnings management is not in shareholders' interests, and we suspect that this is the type of earnings management that both auditors and regulators charged with overseeing financial reporting are most concerned about. Auditors care more about income increasing earnings management (Elliott, Nelson and Tarpley, 2002) and are more likely to be sued when earnings are overstated (St. Pierre and Anderson, 1984). Regulators are more likely to face unpleasant publicity and scrutiny when earnings are overstated. Indeed, most AAER activity in the United States is focused on income increasing earnings management that is apparently undertaken for capital market reasons (Dechow et al., 2011). Hence, we conjecture, but cannot test, that the regulatory forbearance we document is due to one of two reasons, which cannot be disentangled in our setting but could be in future research. One possibility is that regulators do not constrain the earnings management in our setting even though they detect it because it is in shareholders' interests and hence is unlikely to result in any negative outcome for the regulators or auditors if the earnings management is permitted. Alternatively, it could be that auditors and regulators are focused on income increasing earnings management and simply fail to detect the income decreasing earnings management that takes place in our setting. Future research can shed further light on this issue by identifying settings in which there is 1) income increasing earnings management that is in capital providers' interests, and 2) income decreasing earnings management that is not in capital providers' interests. While this issue clearly deserves more study, our results suggest that concluding that

splits of the data as not all countries contribute equal numbers of sample firm-years. If we partition the sample based on the sample firmyear median, the partitions are more balanced and the results are similar. We also examined the sample of countries that Christensen et al. (2013) identify as countries that changed their enforcement of financial reporting around the time of IFRS adoption. We separately examine the periods before and then after these enforcement changes. Because there are only six countries and limited data for them, these tests produce insignificant earnings management in each sample, and, not surprisingly, show no differences between the pre and post enforcement change periods. 
better legal and regulatory institutions help curb all types of earnings management based on the prior literature may not be appropriate.

A third possibility is that prior international studies using broad samples of firms capture cross-country variation in earnings informativeness that is shaped by regulatory and legal institutions but is unrelated to earnings management. While some of the variation in earnings informativeness captured in prior research may be related to earnings management, it may simply reflect the fact that some regulatory and legal structures do not provide incentives to make earnings informative, or provide incentives to pursue other financial reporting objectives (e.g., tax or contractual considerations). If this is true the results from the prior literature and our study might be best interpreted as evidence that regulatory and legal institutions affect overall earnings informativeness in a country rather than earnings management per se. ${ }^{39}$

\section{Section 6 - Conclusions and Suggestions for Future Research}

We examine earnings management in European Union (EU) firms that initiate an antidumping trade investigation against foreign exporters that allegedly dump goods into the EU. We first document sample-wide income decreasing earnings management around the initiation of an antidumping investigation. We also examine some novel and unique setting specific factors that could influence the costs and benefits of earnings management in our setting. We document that earnings management is more pronounced in those cases in which the petitioning firms' accounting data directly affect the magnitude of the tariffs imposed in the trade investigation. Earnings management by sample firms is more pronounced in antidumping cases with fewer sample petitioning firms and when sample petitioning firms are more distant, suggesting that free-rider and coordination issues cause firms to manage earnings less. Finally, we document that earnings management is more pronounced when the petitioning firm is located in a country with high levels of exports to the countries accused of dumping goods into the EU in the petition. This result suggests that concerns over retaliation may dampen regulators' willingness to assign tariffs, perhaps because the home country of the petitioning firm is less supportive of the case. This may cause petitioning firms to turn to earnings management to show greater injury to enhance their likelihood of success.

\footnotetext{
${ }^{39}$ Of course all cross-sectional analyses that are based on country-characteristics may suffer from an omitted variables problem. There are many country characteristics that could affect reporting incentives, and in general those characteristics are correlated. In general cross-sectional analyses based on country-characteristics should be interpreted cautiously.
} 
We also document that raising equity or debt financing during the antidumping investigation moderates this income decreasing earnings management. We find that earnings management does not differ between firms domiciled in countries with better legal enforcement or regulatory quality and firms domiciled in countries with worse legal enforcement and regulatory quality.

Given the importance of trade regulation to the world economy and the extensive development of trade regulation since the 1980s, including the introduction of the World Trade Organization, additional evidence beyond that documented in Jones (1991) on the use of accounting data in trade regulation, and the incentives this creates, is important. Our results have clear implications for international trade scholars and regulators because our results suggest predictable biases are introduced in the antidumping investigation process. In addition, the models used to detect earnings management have been modified since Jones (1991) and our tests suggest that current research methods can be effective in detecting accrual based earnings management. We highlight the importance of understanding how accounting data are used in trade investigations and understanding how firms respond to those uses, and encourage researchers to consider how accounting data are used in other international commercial settings beyond capital markets. While we acknowledge that there is a significant investment required to understand these settings, we believe that the potential contributions to our understanding of how accounting data affect commercial activity internationally justify incurring the costs to make those investments.

There are also limitations to our analyses. Our evidence of earnings management is indirect because we observe the output of the reporting process and cannot observe willful interventions in that process. Our test procedures help to mitigate risk that our tests document actual financial injury from dumping rather than earnings management, but we cannot completely rule out that possibility. For example, it is possible that some of our crosssectional tests partition firms based on the extent of actual injury and not just on the strength of the incentives for earnings management. As a result, we suggest caution in interpreting the evidence produced by our analyses. 
Ahmed, A., M. Neel and D. Wang. 2013. Does Mandatory Adoption of IFRS Improve Accounting Quality? Contemporary Accounting Research, 30: 1344-1372.

Ball, R. 2013. Accounting Informs Investors and Earnings Management is Rife: Two Questionable Beliefs. Accounting Horizons, 27: 847-853

Ball, R., A. Robin and J. S. Wu. 2003. Incentives versus Standards: Properties of Accounting Income in Four East Asian Countries. Journal of Accounting and Economics 36: 235-270

Ball, R. and L. Shivakumar. 2005. Earnings Quality in UK Private Firms: Comparative Loss Recognition Timeliness. Journal of Accounting and Economics, 39: 83-128.

Barton, J., J. Goldstein, T. Josling and R. Steinberg. 2006. The Evolution of the Trade Regime: Politics, Law and Economics of the GATT and the WTO. Princeton University Press.

Barton, J. and P. J. Simko. 2002. The Balance Sheet as an Earnings Management Constraint. The Accounting Review, 77: 1-27.

Bhagwati, J. 1982. Directly Unproductive, Profit-Seeking (DUP) Activities. Journal of Political Economy, 90: 988-1002.

Bhattacharya, U., H. Daouk and M. Welker. 2003. The World Price of Earnings Opacity. The Accounting Review, 78: 641-678.

Blonigen, B. and C. Bown. 2003. Antidumping and Retaliation Threats. Journal of International Economics, 60: 249-273

Blonigen, B. and T. Prusa. 2003. Chapter 9: Antidumping in Handbook of International Trade: Volume 1, edited by Choi, E.K. and J. Harrigan. Blackwell Reference Online.

Bown, Chad P. (2012) "Global Antidumping Database," available at http://econ.worldbank.org/ttbd/gad/.

Brown, P., J. Preiato and A. Tarca. 2014. Measuring Country Differences in Enforcement of Accounting Standards: An Audit and Enforcement Proxy. Journal of Business Finance \& Accounting, 41: 1-52.

Burgstahler, D., L. Hail and C. Leuz. 2006. The Importance of Reporting Incentives: Earnings Management in European Private and Public Firms. The Accounting Review, 81: 983-1016.

Cahan, S. 1992. The Effect of Antitrust Investigations on Discretionary Accruals: A Refined Test of the Political Cost Hypothesis. The Accounting Review, 67: 77-95.

Chen, W., P. Hribar and S. Melessa, "Two-Step Regression Analysis and Biased Estimates in Accounting Research: An Application of the Frisch-Waugh-Lovell Theorem" working paper available at: https://papers.ssrn.com/sol3/papers.cfm?abstract id=2597429

Christensen, H., L. Hail and C. Leuz. 2013, Mandatory IFRS Reporting and Changes in Enforcement. Journal of Accounting and Economics, 56: 147-177.

Dechow, P. and I. Dichev. 2002. The Quality of Accruals and Earnings: The Role of Accrual Estimation Errors. The Accounting Review 77: 35-59 
Dechow, P., W. Ge, C. Larson and R. Sloan. 2011. Predicting Material Accounting Misstatements. Contemporary Accounting Research 28 (Spring), pp. 17-82.

Dechow, P., W. Ge and C. Schrand. 2010. Understanding Earnings Quality: A Review of the Proxies, Their Determinants and Their Consequences. Journal of Accounting and Economics, 50: 344-401.

Dechow, P., A. Hutton, J.H. Kim and R. Sloan. 2012. Detecting Earnings Management: A New Approach. Journal of Accounting Research, 50: 275-334.

Ecker, F., J. Francis, P. Olsson and K. Schipper. 2013. Estimation Sample Selection for Discretionary Accruals Models. Journal of Accounting and Economics, 56: 190-211.

Elliott, J., M. Nelson and R. Tarpley. 2002. Evidence from Auditors About Managers' and Auditors' EarningsManagement Decisions. The Accounting Review, 77 (Supplement): 175-202.

Evenett, S. and E. Vermulst. 2005. The Politicisation of EC Anti-dumping Policy: Member States, Their Votes and the European Commission. World Economy, February. Accessed at www.researchgate.net/publication/4997215

Feinberg, R. and B. Hirsch. 1989. Industry Rent Seeking and the Filing of "Unfair Trade" Complaints. International Journal of Industrial Organization, 7: 325-340.

Francis, J. and D. Wang. 2008. The Joint Effect of Investor Protection and Big 4 Audits on Earnings Quality around the World. Contemporary Accounting Research, 25: 157-191.

González, T., M. Schmid and D. Yermack. 2013. Smokescreen: How Managers Behave When They Have Something To Hide. NBER Working paper, No. 18886.

Godsell, D. 2016. The Market Valuation of Managed Earnings in A Regulatory Setting With Learning Opportunities. Working Paper, University of Illinois at Urbana-Champaign.

Gopalan, R. and S. Jayaram. 2012. Private Control Benefits and Earnings Management: Evidence from Insider Controlled Firms. Journal of Accounting Research, 50: 117-157

Han, J. and S. Wang. 1998. Political Costs and Earnings Management of Oil Companies during the 1990 Persian Gulf Crisis. The Accounting Review, 73: 103-117.

Hansen, W. and T. Prusa, 1997. The Economics and Politics of Trade Policy: An Empirical Analysis of ITC Decision Making. Review of International Economics, 5: 230-245.

Hillman, A., E. Katz and J. Rosenberg. 1987. Workers as Insurance: Anticipated Government Assistance and Factor Demand. Oxford Economic Papers, 39: 813-820.

Johnston, R. and S. Rock. 2005. Earnings Management to Minimize Superfund Clean-up and Transaction Costs. Contemporary Accounting Research, 22: 617-642.

Jones, J. 1991. Earnings Management during Import Relief Investigations. Journal of Accounting Research, 29: 193-228.

Kaufmann, D., A. Kraay and M. Mastruzzi. 2009. Governance Matters VIII: Governance Indicators for 1996 2008. World Bank Policy Research, Washington, D.C. 
Key, K. 1997. Political Cost Incentives for Earnings Management in the Cable Televisions Industry. Journal of Accounting and Economics, 23: 309-337.

La Porta, R., F. Lopez-De-Silanes, A. Shleifer and R. Vishny. 2002. Investor Protection and Corporate Valuation. Journal of Finance, 57: 1147-1170.

Leidy, M., \& B. Hoekman. 1991. Spurious Injury as Indirect Rent-Seeking: Free Trade under the Prospect of Protection. Economics and Politics, 3: 111-137.

Leuz, C., D. Nanda and P. Wysocki. 2003. Earnings Management and Investor Protection: An International Comparison. Journal of Financial Economics, 69: 505-527.

Magnan, M., C. Nadeau and D. Cormier. 1999. Earnings Management during Antidumping Investigations: Analysis and Implications. Canadian Journal of Administrative Sciences, 16 (2): 149-162.

McNichols, M.F. 2002. Discussion of the Quality of Accruals and Earnings: The Role of Accrual Estimation Errors. The Accounting Review, 77: 61-69.

Mensah, Y., J. Considine and L. Oakes. 1994. Statutory Insolvency Regulations and Earnings Management in the Prepaid Health-Care Industry. The Accounting Review, 69: 70-95.

Monem, R. 2003. Earnings Management in Response to the Introduction of the Australian Gold Tax. Contemporary Accounting Research, 20: 747-774.

Naranjo, P., D Saavedra and R. Verdi. 2015. Financial Reporting Regulation and Financing Decisions. Working paper available at http://papers.ssrn.com/sol3/papers.cfm?abstract_id=2147838.

Nelson, D. 2006. The Political Economy of Antidumping: a survey. European Journal of Political Economy, 22: 554-590.

Prusa, T. 1992. Why are So Many Antidumping Petitions withdrawn? Journal of International Economics, 33: 120.

Prusa, T. and S. Skeath. 2002. The Economic and Strategic Motives for Antidumping Filings, NBER Working Paper, No. 8424.

Rayburn, J. and S. Lenway. 1992. An Investigation of the Behavior of Accruals in the Semiconductor Industry: 1985. Contemporary Accounting Research, 9 (2): 237-251.

Roychowdhury, S. 2006. Earnings Management through Real Activities Manipulation. Journal of Accounting and Economics, 42: 335-370.

St. Pierre, K., and J. A. Anderson. 1984. An Analysis of the Factors Associated with Lawsuits against Public Accountants. The Accounting Review 59: 242-263.

Schipper, K. 1989. Commentary on Earnings Management. Accounting Horizons, 3: 91-102.

Staiger, R. and F. Wolak. 1996. Differences in the Uses and Effects of Antidumping law across Import Sources, in: Krueger, A.O. (Ed.), The Political Economy of American Trade Policy. Chicago: University of Chicago Press. 


\section{Appendix: An example of an antidumping case}

We provide a brief snapshot of the data that are available in the World Bank database to illustrate our empirical approach and to highlight the important features of our setting. On August 13, 2009, an investigation was launched into the potential dumping of aluminum wheels into the EU by manufacturers in China. There were nine domestic producers of these wheels named in the investigation, and these producers were domiciled in Germany, the Czech Republic, Switzerland, Poland, Italy, Spain and France. Because China is considered a nonmarket economy, the normal value of most of the wheels covered in the investigation was determined based on the prices that domestic producers in Turkey sold their products for in their home market of Turkey. Based on a comparison of these normal values with the export prices charged by the Chinese exporters, the European Commission determined that Chinese exporters were in fact dumping aluminum wheels in the EU. The European Commission also determined that the industry in the EU was injured by the dumping, and a variety of aggregate industry metrics were cited as evidence of injury. Among these, declining production, capacity utilization, market share, profitability, return on investment, and cash flows were key indicators that the dumping was causing economic injury in the EU industry.

The investigation period covered the year from July 1, 2008 to June 30, 2009, so the focus of the injury determination was on this time period. The EU financial condition during the investigation period was compared to the preceding two years, 2006 and 2007, to determine if there was injury from the alleged dumping. The overall industry profitability as a percentage of sales declined from $3.2 \%$ to negative $5.4 \%$ during the investigation period, and the return on investment fell from 50.8\% in 2006 to negative $40.8 \%$ during the investigation period. These numbers are central to our investigation because we hypothesize that the EU producers of aluminum wheels had strong incentives to manage their accounting data to demonstrate this diminished financial performance during the investigation period. Because there was an affirmative determination of both dumping and injury, antidumping duties were assessed. Importantly, the size of the duty imposed was determined as the amount of duty necessary to allow the industry to return to its pre-dumping profitability of $3.2 \%$ from the level of profitability observed in the investigation period, negative 5.4\%. Hence, in this particular case, the EU producers accounting data in the investigation period and the period immediately preceding the investigation period had a direct impact on the determination of whether the industry had been injured and a direct effect on the magnitude of the duties imposed on the Chinese exporters. 
Table 1 - Sample Selection

This table reports the selection of the trade investigation sample. Panel A lists the home country for our sample firms. Panel B lists the industry composition of our sample, and Panel $\mathrm{C}$ shows the distribution of case initiation dates over time.

Panel A: Country breakdown

\begin{tabular}{|c|c|c|c|c|c|c|}
\hline & \# of cases & $\%$ as total cases & \# of firms & $\%$ as total \# of firms & \# of firm years & $\%$ as total firm years \\
\hline Austria & 10 & $4 \%$ & 7 & $3 \%$ & 53 & $2 \%$ \\
\hline Belgium & 22 & $8 \%$ & 19 & $8 \%$ & 190 & $9 \%$ \\
\hline Czech Republic & 3 & $1 \%$ & 3 & $1 \%$ & 29 & $1 \%$ \\
\hline Germany & 34 & $12 \%$ & 25 & $10 \%$ & 154 & $7 \%$ \\
\hline Spain & 52 & $18 \%$ & 41 & $17 \%$ & 447 & $21 \%$ \\
\hline Finland & 4 & $1 \%$ & 4 & $2 \%$ & 39 & $2 \%$ \\
\hline France & 36 & $13 \%$ & 32 & $13 \%$ & 271 & $13 \%$ \\
\hline United Kingdom & 26 & $9 \%$ & 22 & $9 \%$ & 155 & $7 \%$ \\
\hline Greece & 3 & $1 \%$ & 3 & $1 \%$ & 43 & $2 \%$ \\
\hline Italy & 62 & $22 \%$ & 51 & $21 \%$ & 502 & $24 \%$ \\
\hline Lithuania & 2 & $1 \%$ & 2 & $1 \%$ & 9 & $0 \%$ \\
\hline Netherlands & 8 & $3 \%$ & 8 & $3 \%$ & 65 & $3 \%$ \\
\hline Poland & 9 & $3 \%$ & 9 & $4 \%$ & 62 & $3 \%$ \\
\hline Portugal & 3 & $1 \%$ & 3 & $1 \%$ & 28 & $1 \%$ \\
\hline Sweden & 7 & $2 \%$ & 7 & $3 \%$ & 61 & $3 \%$ \\
\hline Slovenia & 2 & $1 \%$ & 2 & $1 \%$ & 6 & $0 \%$ \\
\hline Slovakia & 2 & $1 \%$ & 2 & $1 \%$ & 15 & $1 \%$ \\
\hline Total & 285 & $100 \%$ & 240 & $100 \%$ & 2,129 & $100 \%$ \\
\hline \multicolumn{7}{|c|}{ Panel B: Industry breakdown } \\
\hline & \# of cases & $\%$ as total cases & \# of firms & $\%$ as total \# of firms & \# of firm years & $\%$ as total firm years \\
\hline Non-durable & 35 & $12 \%$ & 31 & $13 \%$ & 290 & $14 \%$ \\
\hline Consumer Durable & 18 & $6 \%$ & 17 & $7 \%$ & 160 & $8 \%$ \\
\hline Manufacturing & 194 & $68 \%$ & 158 & $66 \%$ & 1446 & $68 \%$ \\
\hline Energy & 5 & $2 \%$ & 5 & $2 \%$ & 44 & $2 \%$ \\
\hline High Tech & 6 & $2 \%$ & 6 & $3 \%$ & 56 & $3 \%$ \\
\hline Telecommunication & 2 & $1 \%$ & 2 & $1 \%$ & 6 & $0 \%$ \\
\hline Health & 2 & $1 \%$ & 2 & $1 \%$ & 20 & $1 \%$ \\
\hline Other & 23 & $8 \%$ & 19 & $8 \%$ & 107 & $5 \%$ \\
\hline Total & 285 & $100 \%$ & 240 & $100 \%$ & 2,129 & $100 \%$ \\
\hline \multicolumn{7}{|c|}{ Panel C: Year breakdown } \\
\hline & \#\# of cases & $\%$ as total cases & \# of firm years & $\%$ as total firm years & & \\
\hline 1996 and before & 28 & $10 \%$ & 98 & $5 \%$ & & \\
\hline 1997 & 19 & $7 \%$ & 122 & $6 \%$ & & \\
\hline 1998 & 29 & $10 \%$ & 131 & $6 \%$ & & \\
\hline 1999 & 27 & $9 \%$ & 135 & $6 \%$ & & \\
\hline 2000 & 15 & $5 \%$ & 142 & $7 \%$ & & \\
\hline 2001 & 8 & $3 \%$ & 145 & $7 \%$ & & \\
\hline 2002 & 13 & $5 \%$ & 138 & $6 \%$ & & \\
\hline 2003 & 19 & $7 \%$ & 126 & $6 \%$ & & \\
\hline 2004 & 18 & $6 \%$ & 126 & $6 \%$ & & \\
\hline 2005 & 15 & $5 \%$ & 128 & $6 \%$ & & \\
\hline 2006 & 13 & $5 \%$ & 147 & $7 \%$ & & \\
\hline 2007 & 33 & $12 \%$ & 148 & $7 \%$ & & \\
\hline 2008 & 11 & $4 \%$ & 150 & $7 \%$ & & \\
\hline 2009 & 24 & $8 \%$ & 149 & $7 \%$ & & \\
\hline 2010 & 10 & $4 \%$ & 141 & $7 \%$ & & \\
\hline 2011 & 3 & $1 \%$ & 103 & $5 \%$ & & \\
\hline Total & 285 & $100 \%$ & 2,129 & $100 \%$ & & \\
\hline
\end{tabular}




\section{Table 2 - Descriptive Statistics}

This table reports the summary statistics for the main variables used in this paper. TOT_ACC is measured as the change in current assets minus the change in current liabilities (adjusted for current liabilities used for financing) minus depreciation expense. WC_ACC is working capital accruals, measured as the change in current assets minus the change in current liabilities (adjusted for current liabilities used for financing). 1/TotAssets is the inverse of lagged total assets. $\mathrm{CFO}_{t-1, t, t+1}$ are cash flows from operations in year $t-1, t$ and $t+1$ scaled by lagged total assets. PP\&E is net property, plant and equipment, scaled by lagged total assets. $\triangle \mathrm{REV}-\triangle \mathrm{AR}$ is the change in sales minus the change in accounts receivable, scaled by lagged total assets. Size is the natural logarithm of total sales revenue. Leverage is book leverage, defined as long-term debt plus the current portion of long-term debt, scaled by total assets. Growth is sales growth, defined as sales growth from $t-1$ to $t$. Std(sales) is operating volatility, defined as the standard deviation of sales over the past three years, i.e., $t$, $t$-1, $t$-2. NOA is net operating assets, calculated as the sum of shareholders equity and interest-bearing debt, minus cash assets, scaled by sales. Return is the median contemporaneous annual excess stock return (annual raw return minus the market index return) for all public firms that are from the same Fama-French 30 industry from the country that is home to the petitioning firm. We extract return data from Worldscope. Panel A provides descriptive statistics for the trade investigation sample and the matched sample. Panel B shows how the components of earnings for trade investigation behave around investigation initiation dates. Panel $\mathrm{C}$ shows the distribution of event firm-years across our primary sample-wide partitions to assess the independence of our sample partitions.

Panel A: Summary statistics for the baseline sample

\begin{tabular}{|c|c|c|c|c|c|c|c|c|c|c|c|c|}
\hline \multirow[b]{2}{*}{ Variable } & \multicolumn{4}{|c|}{ Trade investigation sample $(\mathrm{N}=2,129)$} & \multicolumn{4}{|c|}{ "Matched sample $(\mathrm{N}=11,281)$} & \multicolumn{4}{|c|}{ Full sample $(\mathrm{N}=13,410)$} \\
\hline & Mean & $\mathrm{P} 25$ & Median & P75 & Mean & $\mathrm{P} 25$ & Median & $\mathrm{P} 75$ & Mean & $\mathrm{P} 25$ & Median & $\mathrm{P} 75$ \\
\hline TOT_ACC & -0.038 & -0.104 & -0.042 & 0.024 & -0.034 & -0.095 & -0.034 & 0.023 & -0.035 & -0.097 & -0.035 & 0.023 \\
\hline WC_ACC & 0.014 & -0.048 & 0.007 & 0.071 & 0.010 & -0.045 & 0.006 & 0.062 & 0.011 & -0.046 & 0.006 & 0.064 \\
\hline 1/TotAssets & 0.058 & 0.002 & 0.011 & 0.043 & 0.055 & 0.002 & 0.011 & 0.042 & 0.055 & 0.002 & 0.011 & 0.042 \\
\hline PP\&E & 0.324 & 0.186 & 0.313 & 0.447 & 0.281 & 0.083 & 0.221 & 0.412 & 0.288 & 0.094 & 0.239 & 0.421 \\
\hline$\Delta \mathrm{REV}-\Delta \mathrm{AR}$ & 0.049 & -0.092 & 0.045 & 0.184 & 0.052 & -0.066 & 0.025 & 0.158 & 0.051 & -0.069 & 0.028 & 0.163 \\
\hline $\mathrm{CFO}_{t-1}$ & 0.066 & -0.004 & 0.065 & 0.139 & 0.064 & -0.008 & 0.062 & 0.132 & 0.065 & -0.008 & 0.063 & 0.134 \\
\hline $\mathrm{CFO}$ & 0.066 & -0.002 & 0.067 & 0.138 & 0.065 & -0.005 & 0.064 & 0.134 & 0.065 & -0.004 & 0.064 & 0.135 \\
\hline $\mathrm{CFO}_{t+1}$ & 0.063 & -0.005 & 0.066 & 0.141 & 0.066 & -0.006 & 0.062 & 0.139 & 0.066 & -0.006 & 0.063 & 0.140 \\
\hline Size & 4.781 & 3.231 & 4.670 & 6.140 & 4.643 & 3.145 & 4.538 & 6.065 & 4.664 & 3.168 & 4.558 & 6.076 \\
\hline Leverage & 0.202 & 0.038 & 0.169 & 0.324 & 0.202 & 0.013 & 0.135 & 0.324 & 0.202 & 0.015 & 0.142 & 0.324 \\
\hline Growth & 0.064 & -0.096 & 0.050 & 0.199 & 0.062 & -0.077 & 0.041 & 0.178 & 0.062 & -0.079 & 0.042 & 0.181 \\
\hline Std(sales) & 0.164 & 0.061 & 0.114 & 0.205 & 0.157 & 0.044 & 0.096 & 0.193 & 0.158 & 0.047 & 0.099 & 0.195 \\
\hline $\mathrm{NOA}_{t-1}$ & 1.075 & 0.286 & 0.477 & 0.702 & 1.460 & 0.185 & 0.397 & 0.751 & 1.399 & 0.201 & 0.412 & 0.735 \\
\hline Return & -0.030 & -0.184 & -0.045 & 0.096 & -0.039 & -0.176 & -0.052 & 0.073 & -0.038 & -0.177 & -0.052 & 0.079 \\
\hline
\end{tabular}

Panel B: Summary statistics for the trade investigation sample across years around the investigation period

\begin{tabular}{|c|c|c|c|c|c|c|c|c|c|c|c|c|}
\hline \multirow[b]{2}{*}{ Year } & \multicolumn{4}{|c|}{ TOT_ACC } & \multicolumn{4}{|c|}{ WC_ACC } & \multicolumn{4}{|c|}{$\mathrm{CFO}$} \\
\hline & Mean & $\mathrm{P} 25$ & Median & $\mathrm{P} 75$ & Mean & $\mathrm{P} 25$ & Median & $\mathrm{P} 75$ & Mean & $\mathrm{P} 25$ & Median & $\mathrm{P} 75$ \\
\hline Non-event years & -0.040 & -0.104 & -0.043 & 0.023 & 0.013 & -0.051 & 0.006 & 0.074 & 0.073 & 0.002 & 0.072 & 0.149 \\
\hline Event year-3 & -0.028 & -0.099 & -0.032 & 0.031 & 0.023 & -0.034 & 0.011 & 0.085 & 0.078 & -0.012 & 0.061 & 0.148 \\
\hline Event year-2 & -0.040 & -0.122 & -0.040 & 0.019 & 0.011 & -0.054 & 0.014 & 0.064 & 0.086 & 0.011 & 0.088 & 0.148 \\
\hline Event year-1 & -0.016 & -0.088 & -0.022 & 0.049 & 0.035 & -0.031 & 0.022 & 0.093 & 0.051 & -0.029 & 0.053 & 0.121 \\
\hline Event year & -0.031 & -0.095 & -0.041 & 0.024 & 0.018 & -0.041 & 0.012 & 0.061 & 0.048 & -0.011 & 0.047 & 0.118 \\
\hline Event year+1 & -0.061 & -0.104 & -0.059 & -0.011 & -0.008 & -0.058 & -0.003 & 0.041 & 0.078 & 0.010 & 0.072 & 0.133 \\
\hline Event year+2 & -0.032 & -0.115 & -0.036 & 0.032 & 0.017 & -0.045 & 0.010 & 0.076 & 0.054 & -0.005 & 0.065 & 0.138 \\
\hline Event year+3 & -0.045 & -0.118 & -0.047 & 0.027 & 0.004 & -0.056 & 0.003 & 0.071 & 0.065 & -0.002 & 0.078 & 0.146 \\
\hline
\end{tabular}

Panel C: Numbers of event firm-years across primary sample-wide partitions

\begin{tabular}{|c|c|c|c|c|c|c|c|c|c|c|}
\hline & $\begin{array}{l}\text { High \% of } \\
\text { injury- } \\
\text { implied duty }\end{array}$ & $\begin{array}{c}\# \\
\text { petitioners } \\
<=2\end{array}$ & Proximate & $\begin{array}{c}\text { Large export to } \\
\text { the defendant } \\
\text { country }\end{array}$ & $\begin{array}{l}\text { No new } \\
\text { financing }\end{array}$ & $\begin{array}{l}\text { Strong legal } \\
\text { enforcement }\end{array}$ & $\begin{array}{l}\text { High } \\
\text { regulatory } \\
\text { quality }\end{array}$ & $\begin{array}{l}\text { High } \\
\text { audit } \\
\text { score }\end{array}$ & $\begin{array}{c}\text { High } \\
\text { enforce } \\
\text { score }\end{array}$ & $\begin{array}{l}\text { High } \\
\text { total } \\
\text { score }\end{array}$ \\
\hline High $\%$ of injury-implied duty & 148 & & & & & & & & & \\
\hline$\#$ petitioners $<=2$ & 91 & 188 & & & & & & & & \\
\hline Proximate & 48 & 82 & 92 & & & & & & & \\
\hline $\begin{array}{l}\text { Large export to the defendant } \\
\text { country }\end{array}$ & 74 & 67 & 41 & 134 & & & & & & \\
\hline No new financing & 79 & 108 & 50 & 78 & 156 & & & & & \\
\hline Strong legal enforcement & 75 & 107 & 43 & 71 & 90 & 147 & & & & \\
\hline High regulatory quality & 83 & 107 & 40 & 70 & 94 & 116 & 157 & & & \\
\hline High audit score & 79 & 86 & 45 & 89 & 77 & 75 & 97 & 149 & & \\
\hline High enforce score & 95 & 117 & 63 & 101 & 99 & 99 & 83 & 119 & 181 & \\
\hline High total score & 96 & 120 & 59 & 107 & 104 & 95 & 91 & 142 & 167 & 190 \\
\hline
\end{tabular}


Table 3 - Sample-Wide Regression Results

This table reports the baseline test that examines sample-wide earnings management in periods around the initiation of an antidumping trade investigation. Columns (1) and (2) present the results of estimating the expanded specification detailed in equation (1) while columns (3) and (4) show the results of estimating the collapsed specification detailed in equation (2). Columns (5)-(8) repeat the analysis reported in columns (1)-(4) including firm fixed effects. TOT_ACC is measured as the change in current assets minus the change in current liabilities (adjusted for current liabilities used for financing) minus depreciation expense. WC_ACC is working capital accruals, measured as the change in current assets minus the change in current liabilities (adjusted for current liabilities used for financing). 1/TotAssets is the inverse of lagged total assets. $\mathrm{CFO}_{t-1, t, t+1}$ are cash flows from operations in year $t-1, t$ and $t+1$ scaled by lagged total assets. PP\&E is net property, plant and equipment, scaled by lagged total assets. $\triangle \mathrm{REV}-\Delta \mathrm{AR}$ is the change in sales minus the change in accounts receivable, scaled by lagged total assets. Other control variables are defined in Table 2. Standard errors are two-way clustered by both firm and year. T-statistics are presented underneath the coefficient estimates. $* * *, * *$, and $*$ denote significance levels at $1 \%, 5 \%$, and $10 \%$, respectively.

\begin{tabular}{|c|c|c|c|c|c|c|c|c|}
\hline & (1) & (2) & (3) & (4) & (5) & (6) & (7) & (8) \\
\hline & TOT_ACC & WC_ACC & TOT_ACC & WC_ACC & TOT_ACC & WC_ACC & TOT_ACC & WC_ACC \\
\hline 1/TotAssets & $\begin{array}{c}0.0271 * * * \\
(3.01)\end{array}$ & $\begin{array}{c}0.0424 * * * \\
(5.53)\end{array}$ & $\begin{array}{c}0.0271^{* * * *} \\
\quad(3.00)\end{array}$ & $\begin{array}{c}0.0424 * * * \\
(5.53)\end{array}$ & $\begin{array}{c}0.0308 * \\
(1.68)\end{array}$ & $\begin{array}{c}0.0432 * * \\
(2.26)\end{array}$ & $\begin{array}{c}0.0308 * \\
(1.68)\end{array}$ & $\begin{array}{c}0.0432 * * \\
(2.26)\end{array}$ \\
\hline PP\&E & $\begin{array}{c}-0.0376^{* * * *} \\
(-6.95)\end{array}$ & $\begin{array}{c}0.00666 \\
(1.31)\end{array}$ & $\begin{array}{c}-0.0376^{* * * *} \\
(-6.96)\end{array}$ & $\begin{array}{c}0.00663 \\
(1.31)\end{array}$ & $\begin{array}{c}-0.0341 \text { *** } \\
(-3.73)\end{array}$ & $\begin{array}{c}0.00307 \\
(0.35)\end{array}$ & $\begin{array}{c}-0.0342 \text { *** } \\
(-3.75)\end{array}$ & $\begin{array}{c}0.00301 \\
(0.34)\end{array}$ \\
\hline$\Delta \mathrm{REV}-\Delta \mathrm{AR}$ & $\begin{array}{c}0.0269^{* * * *} \\
(5.18)\end{array}$ & $\begin{array}{c}0.0264 * * * \\
(4.88)\end{array}$ & $\begin{array}{c}0.0269 \text { *** } \\
(5.19)\end{array}$ & $\begin{array}{c}0.0264 * * * \\
(4.92)\end{array}$ & $\begin{array}{c}0.0255^{* * *} * \\
(4.24)\end{array}$ & $\begin{array}{c}0.0266 * * * \\
(4.97)\end{array}$ & $\begin{array}{c}0.0255^{* * *} \\
\quad(4.25)\end{array}$ & $\begin{array}{c}0.0265^{* * * *} \\
(4.98)\end{array}$ \\
\hline $\mathrm{CFO}_{t-1}$ & $\begin{array}{c}0.0987 * * * \\
(10.29)\end{array}$ & $\begin{array}{c}0.141 \text { *** } \\
(10.28)\end{array}$ & $\begin{array}{c}0.0987 * * * \\
(10.33)\end{array}$ & $\begin{array}{c}0.141 * * * \\
(10.34)\end{array}$ & $\begin{array}{c}0.0629 * * * \\
(7.22)\end{array}$ & $\begin{array}{c}0.0761 * * * \\
(8.69)\end{array}$ & $\begin{array}{c}0.0630^{* * * *} \\
(7.20)\end{array}$ & $\begin{array}{c}0.0761 * * * \\
(8.67)\end{array}$ \\
\hline $\mathrm{CFO}$ & $\begin{array}{c}-0.780 * * * \\
(-53.26)\end{array}$ & $\begin{array}{c}-0.718 * * * \\
(-59.22)\end{array}$ & $\begin{array}{c}-0.780 * * * \\
(-52.93)\end{array}$ & $\begin{array}{c}-0.718 * * * \\
(-58.73)\end{array}$ & $\begin{array}{c}-0.828 * * * \\
(-55.45)\end{array}$ & $\begin{array}{c}-0.799 * * * \\
(-55.40)\end{array}$ & $\begin{array}{c}-0.828 * * * \\
(-55.19)\end{array}$ & $\begin{array}{c}-0.799 * * * \\
(-55.11)\end{array}$ \\
\hline $\mathrm{CFO}_{t+1}$ & $\begin{array}{c}0.102 * * * \\
(8.20)\end{array}$ & $\begin{array}{c}0.134 * * * \\
(13.44)\end{array}$ & $\begin{array}{c}0.102 * * * \\
(8.23)\end{array}$ & $\begin{array}{c}0.134 * * * \\
(13.48)\end{array}$ & $\begin{array}{c}0.0729 * * * \\
(7.09)\end{array}$ & $\begin{array}{c}0.0787 * * * \\
(7.84)\end{array}$ & $\begin{array}{c}0.0729 * * * \\
\quad(7.11)\end{array}$ & $\begin{array}{c}0.0787 * * * \\
(7.84)\end{array}$ \\
\hline Event year-3 & $\begin{array}{c}0.0114 \\
(1.35)\end{array}$ & $\begin{array}{c}0.00791 \\
(1.11)\end{array}$ & & & $\begin{array}{c}0.0100 \\
(1.08)\end{array}$ & $\begin{array}{c}0.00861 \\
(1.06)\end{array}$ & & \\
\hline Event year-2 & $\begin{array}{c}0.00914^{*} \\
(1.91)\end{array}$ & $\begin{array}{c}0.00658 \\
(1.33)\end{array}$ & & & $\begin{array}{c}0.00867 \\
(1.46)\end{array}$ & $\begin{array}{c}0.00810 \\
(1.46)\end{array}$ & & \\
\hline Event year-1 & $\begin{array}{c}0.00212 \\
(0.33)\end{array}$ & $\begin{array}{c}0.000855 \\
(0.13)\end{array}$ & & & $\begin{array}{c}0.00250 \\
(0.47)\end{array}$ & $\begin{array}{c}0.00208 \\
(0.38)\end{array}$ & & \\
\hline Event year & $\begin{array}{c}-\mathbf{0 . 0 1 1 9} * * \\
(-2.18)\end{array}$ & $\begin{array}{c}-0.0124 * * \\
(-2.40)\end{array}$ & & & $\begin{array}{c}-0.0126 * * \\
(-2.16)\end{array}$ & $\begin{array}{c}-0.0137 * * \\
(-2.36)\end{array}$ & & \\
\hline Event year+1 & $\begin{array}{c}-0.0152 * * * * \\
(-2.81)\end{array}$ & $\begin{array}{c}-0.0116 * \\
(-1.93)\end{array}$ & & & $\begin{array}{c}-0.0165 * * * \\
(-2.60)\end{array}$ & $\begin{array}{c}-0.0128 * * \\
(-2.04)\end{array}$ & & \\
\hline Event year+2 & $\begin{array}{c}-0.00290 \\
(-0.32)\end{array}$ & $\begin{array}{c}-0.00451 \\
(-0.51)\end{array}$ & & & $\begin{array}{c}-0.00236 \\
(-0.27)\end{array}$ & $\begin{array}{c}-0.00312 \\
(-0.37)\end{array}$ & & \\
\hline Event year +3 & $\begin{array}{c}-0.00812 \\
(-1.36)\end{array}$ & $\begin{array}{c}-0.00830 \\
(-1.50)\end{array}$ & & & $\begin{array}{c}-0.00898 \\
(-1.60)\end{array}$ & $\begin{array}{c}-0.00929 \\
(-1.58)\end{array}$ & & \\
\hline Pre & & & $\begin{array}{c}0.00762 \\
(1.63)\end{array}$ & $\begin{array}{c}0.00509 \\
(1.12)\end{array}$ & & & $\begin{array}{c}0.00682 \\
(1.33)\end{array}$ & $\begin{array}{c}0.00599 \\
(1.27)\end{array}$ \\
\hline Current & & & $\begin{array}{c}-0.0133 * * * \\
(-2.64)\end{array}$ & $\begin{array}{c}-0.0119 * * \\
(-2.45)\end{array}$ & & & $\begin{array}{c}-0.0142 * * * \\
(-2.65)\end{array}$ & $\begin{array}{c}-0.0131 * * * \\
(-2.60)\end{array}$ \\
\hline Post & & & $\begin{array}{c}-0.00563 \\
(-1.06)\end{array}$ & $\begin{array}{c}-0.00636 \\
(-1.12)\end{array}$ & & & $\begin{array}{c}-0.00513 \\
(-0.95)\end{array}$ & $\begin{array}{c}-0.00594 \\
(-1.09)\end{array}$ \\
\hline Firm characteristics & & & & & & & & \\
\hline Size & $\begin{array}{c}0.00198 * * * \\
(2.84)\end{array}$ & $\begin{array}{c}0.00256^{* * *} * \\
(3.98)\end{array}$ & $\begin{array}{c}0.00197 * * * \\
(2.83)\end{array}$ & $\begin{array}{c}0.00255^{* * *} \\
(4.01)\end{array}$ & $\begin{array}{c}0.00634 * * * \\
\quad(3.22)\end{array}$ & $\begin{array}{c}0.00919 * * * \\
(4.53)\end{array}$ & $\begin{array}{c}0.00635^{* * *} * \\
\quad(3.22)\end{array}$ & $\begin{array}{c}0.00919^{* * * *} \\
\quad(4.53)\end{array}$ \\
\hline Leverage & $\begin{array}{c}-0.0431 \text { *** } \\
(-6.98)\end{array}$ & $\begin{array}{c}-0.0261 \text { *** } \\
(-3.48)\end{array}$ & $\begin{array}{c}-0.0431 \text { *** } \\
(-6.96)\end{array}$ & $\begin{array}{c}-0.0262 * * * \\
(-3.47)\end{array}$ & $\begin{array}{c}-0.0532^{* * * *} \\
(-6.69)\end{array}$ & $\begin{array}{c}-0.0391 * * * \\
(-5.22)\end{array}$ & $\begin{array}{c}-0.0534 * * * * \\
(-6.72)\end{array}$ & $\begin{array}{c}-0.0392^{* * * *} \\
(-5.23)\end{array}$ \\
\hline Std(sales) & $\begin{array}{c}-0.0153^{* * *} * \\
(-3.15)\end{array}$ & $\begin{array}{c}-0.00957 * * \\
(-2.05)\end{array}$ & $\begin{array}{c}-0.0153 * * * \\
(-3.11)\end{array}$ & $\begin{array}{c}-0.00952^{* *} \\
(-2.04)\end{array}$ & $\begin{array}{c}-0.00851 \\
(-1.21)\end{array}$ & $\begin{array}{c}-0.00948 \\
(-1.41)\end{array}$ & $\begin{array}{c}-0.00839 \\
(-1.19)\end{array}$ & $\begin{array}{c}-0.00937 \\
(-1.39)\end{array}$ \\
\hline $\mathrm{NOA}_{t-1}$ & $\begin{array}{c}0.000245 \\
(1.09)\end{array}$ & $\begin{array}{c}-0.000569^{* * *} \\
(-3.13)\end{array}$ & $\begin{array}{c}0.000246 \\
(1.03)\end{array}$ & $\begin{array}{c}-0.000568 * * * \\
(-3.15)\end{array}$ & $\begin{array}{c}-0.0000878 \\
(-0.41)\end{array}$ & $\begin{array}{c}-0.000443^{*} \\
(-1.78)\end{array}$ & $\begin{array}{c}-0.0000853 \\
(-0.39)\end{array}$ & $\begin{array}{c}-0.000441^{*} \\
(-1.77)\end{array}$ \\
\hline Return & $\begin{array}{c}0.00263 \\
(0.58)\end{array}$ & $\begin{array}{c}0.00141 \\
(0.41)\end{array}$ & $\begin{array}{c}0.00250 \\
(0.56)\end{array}$ & $\begin{array}{c}0.00134 \\
(0.40)\end{array}$ & $\begin{array}{c}0.00255 \\
(0.91)\end{array}$ & $\begin{array}{c}0.00267 \\
(1.11)\end{array}$ & $\begin{array}{c}0.00241 \\
(0.87)\end{array}$ & $\begin{array}{c}0.00258 \\
(1.08)\end{array}$ \\
\hline Event Firm Indicator & $\begin{array}{c}0.00203 \\
(0.49)\end{array}$ & $\begin{array}{c}0.00528 \\
(1.23)\end{array}$ & $\begin{array}{c}0.00190 \\
(0.45)\end{array}$ & $\begin{array}{c}0.00515 \\
(1.19)\end{array}$ & & & & \\
\hline Industry fixed effects & Yes & Yes & Yes & Yes & No & No & No & No \\
\hline Country fixed effects & Yes & Yes & Yes & Yes & No & No & No & No \\
\hline Firm fixed effects & No & No & No & No & Yes & Yes & Yes & Yes \\
\hline Year fixed effects & Yes & Yes & Yes & Yes & Yes & Yes & Yes & Yes \\
\hline $\mathrm{N}$ & 13,410 & 13,410 & 13,410 & 13,410 & 13,410 & 13,410 & 13,410 & 13,410 \\
\hline adj. R-sq & 0.755 & 0.729 & 0.755 & 0.729 & 0.814 & 0.788 & 0.814 & 0.788 \\
\hline
\end{tabular}




\section{Table 4 - Injury Elimination Margin Sample Partition}

This table reports the results showing earnings management in periods around the initiation of an antidumping trade investigation when the sample is partitioned based on the percentage of exporters assessed injury elimination margins. We designate cases in which less than (more than) the median percentage (33\%) of the exporters are assessed the injury elimination margins as low percentage of injury-implied duty cases, respectively. Columns (1) and (2) report the results for the low percentage of injury-implied duty cases and columns (3) and (4) report the results for the high percentage of injury-implied duty cases. TOT_ACC is measured as the change in current assets minus the change in current liabilities (adjusted for current liabilities used for financing) minus depreciation expense. WC_ACC is working capital accruals, measured as the change in current assets minus the change in current liabilities (adjusted for current liabilities used for financing). 1/TotAssets is the inverse of lagged total assets. $\mathrm{CFO}_{t-1, t, t+1}$ are cash flows from operations in year $t-1, t$ and $t+1$ scaled by lagged total assets. PP\&E is net property, plant and equipment, scaled by lagged total assets. $\Delta \mathrm{REV}-\Delta \mathrm{AR}$ is the change in sales minus the change in accounts receivable, scaled by lagged total assets. Other control variables are defined in Table 2. Standard errors are twoway clustered by both firm and year. T-statistics are presented underneath the coefficient estimates. ***, **, and * denote significance levels at $1 \%, 5 \%$, and $10 \%$, respectively.

\begin{tabular}{|c|c|c|c|c|}
\hline & $(1)$ & $(2)$ & $(3)$ & $(4)$ \\
\hline & \multicolumn{2}{|c|}{ Low $\%$ of injury-implied duty } & \multicolumn{2}{|c|}{ High $\%$ of injury-implied duty } \\
\hline & TOT_ACC & WC_ACC & TOT_ACC & WC_ACC \\
\hline $1 /$ TotAssets & $\begin{array}{c}0.00773 \\
(0.70)\end{array}$ & $\begin{array}{c}0.0355 * * * \\
(3.03)\end{array}$ & $\begin{array}{l}0.0479 * * * \\
(2.67)\end{array}$ & $\begin{array}{c}0.0451 * * * \\
(3.19)\end{array}$ \\
\hline PP\&E & $\begin{array}{c}-0.0404 * * * \\
(-6.10)\end{array}$ & $\begin{array}{c}0.00677 \\
(1.11)\end{array}$ & $\begin{array}{c}-0.0309 * * * \\
(-3.95)\end{array}$ & $\begin{array}{c}0.00812 \\
(1.18)\end{array}$ \\
\hline$\Delta \mathrm{REV}-\Delta \mathrm{AR}$ & $\begin{array}{l}0.0279^{* * * *} \\
\quad(4.12)\end{array}$ & $\begin{array}{l}0.0302 * * * \\
\quad(4.01)\end{array}$ & $\begin{array}{l}0.0262 * * * \\
(4.15)\end{array}$ & $\begin{array}{l}0.0262 * * * \\
(4.19)\end{array}$ \\
\hline $\mathrm{CFO}_{t-1}$ & $\begin{array}{c}0.106 * * * \\
(8.60)\end{array}$ & $\begin{array}{l}0.135 * * * \\
(9.52)\end{array}$ & $\begin{array}{l}0.0929 * * * \\
\quad(7.28)\end{array}$ & $\begin{array}{l}0.139 * * * \\
(9.10)\end{array}$ \\
\hline $\mathrm{CFO}$ & $\begin{array}{c}-0.785 * * * \\
(-35.87)\end{array}$ & $\begin{array}{c}-0.747 * * * \\
(-36.55)\end{array}$ & $\begin{array}{c}-0.783 * * * \\
(-40.96)\end{array}$ & $\begin{array}{c}-0.703 * * * \\
(-61.52)\end{array}$ \\
\hline $\mathrm{CFO}_{t+1}$ & $\begin{array}{l}0.104 * * * \\
(8.06)\end{array}$ & $\begin{array}{c}0.130 * * * \\
(10.60)\end{array}$ & $\begin{array}{l}0.101 * * * \\
(7.13)\end{array}$ & $\begin{array}{c}0.139 * * * \\
(13.27)\end{array}$ \\
\hline Pre & $\begin{array}{r}0.0109 \\
(1.57)\end{array}$ & $\begin{array}{c}0.0103 \\
(1.60)\end{array}$ & $\begin{array}{c}0.000733 \\
(0.10)\end{array}$ & $\begin{array}{c}-0.00193 \\
(-0.28)\end{array}$ \\
\hline Current & $\begin{array}{c}-0.00695 \\
(-1.01)\end{array}$ & $\begin{array}{c}-0.00255 \\
(-0.38)\end{array}$ & $\begin{array}{c}-\mathbf{0 . 0 2 0 0} * * * \\
(-3.56)\end{array}$ & $\begin{array}{c}-0.0204 * * * \\
\quad(-3.11)\end{array}$ \\
\hline Post & $\begin{array}{c}-0.00600 \\
(-1.14)\end{array}$ & $\begin{array}{c}-0.00490 \\
(-0.92)\end{array}$ & $\begin{array}{c}-0.00730 \\
(-0.90)\end{array}$ & $\begin{array}{c}-0.00675 \\
(-0.76)\end{array}$ \\
\hline Firm characteristics & Yes & Yes & Yes & Yes \\
\hline Industry fixed effects & Yes & Yes & Yes & Yes \\
\hline Country fixed effects & Yes & Yes & Yes & Yes \\
\hline $\begin{array}{l}\text { Year fixed effects } \\
p \text {-value }\left[\beta_{\text {Current }}{ }^{(3)}<\beta_{\text {Current }}{ }^{(1)}\right]\end{array}$ & Yes & Yes & $\begin{array}{l}\text { Yes } \\
0.04\end{array}$ & Yes \\
\hline$p$-value $\left[\beta_{\text {Current }}{ }^{(4)}<\beta_{\text {Current }}{ }^{(2)}\right]$ & & & & $<0.01$ \\
\hline $\mathrm{N}$ & 6,501 & 6,501 & 7,379 & 7,379 \\
\hline adj. R-sq & 0.760 & 0.744 & 0.753 & 0.722 \\
\hline
\end{tabular}




\section{Table 5 - Further Evidence: Injury Elimination Margins}

This table reports the results showing earnings management in periods around the initiation of an antidumping trade investigation when the sample is partitioned based on the percentage of exporters assessed the injury elimination margin. We repeat the analysis in Table 7 with cases in which at least one, 33\%, and then 50\% of the exporters are assessed the injury elimination margin as high use of injuryimplied duty cases, respectively. Columns (1) and (2) report the results for cases in which there is at least one injury elimination margin, columns (3) and (4) repeat the results that were provided in Table 7 for the sample with above median (33\%) percentage of injury-implied duties for comparative purposes, and columns (5) and (6) report the results for the sample with above 50\% of injury-implied duties. TOT_ACC is measured as the change in current assets minus the change in current liabilities (adjusted for current liabilities used for financing) minus depreciation expense. WC_ACC is working capital accruals, measured as the change in current assets minus the change in current liabilities (adjusted for current liabilities used for financing). 1/TotAssets is the inverse of lagged total assets. $\mathrm{CFO}_{t-1, t, t+1}$ are cash flows from operations in year $t-1, t$ and $t+1$ scaled by lagged total assets. PP\&E is net property, plant and equipment, scaled by lagged total assets. $\triangle \mathrm{REV}-\triangle \mathrm{AR}$ is the change in sales minus the change in accounts receivable, scaled by lagged total assets. Other control variables are defined in Table 2 . Standard errors are two-way clustered by both firm and year. T-statistics are presented underneath the coefficient estimates. $* * *, * *$, and $*$ denote significance levels at $1 \%, 5 \%$, and $10 \%$, respectively.

\begin{tabular}{|c|c|c|c|c|c|c|}
\hline & $(1)$ & $(2)$ & (3) & $(4)$ & $(5)$ & $(6)$ \\
\hline & \multicolumn{2}{|c|}{ At least one injury-implied duty } & \multicolumn{2}{|c|}{$>=33 \%$ of injury-implied duty } & \multicolumn{2}{|c|}{$>=50 \%$ of injury-implied duty } \\
\hline & TOT_ACC & WC_ACC & TOT_ACC & WC_ACC & TOT_ACC & WC_ACC \\
\hline 1/TotAssets & $\begin{array}{c}0.0394 * * \\
(2.23)\end{array}$ & $\begin{array}{c}0.0447 * * * \\
(3.13)\end{array}$ & $\begin{array}{c}0.0479 * * * \\
(2.67)\end{array}$ & $\begin{array}{c}0.0451 * * * \\
(3.19)\end{array}$ & $\begin{array}{c}0.0429 * * * \\
(2.75)\end{array}$ & $\begin{array}{c}0.0327 * * \\
(2.30)\end{array}$ \\
\hline PP\&E & $\begin{array}{c}-0.0357 * * * \\
(-5.13)\end{array}$ & $\begin{array}{c}0.00674 \\
(1.07)\end{array}$ & $\begin{array}{c}-0.0309 * * * \\
(-3.95)\end{array}$ & $\begin{array}{c}0.00812 \\
(1.18)\end{array}$ & $\begin{array}{c}-0.0286^{* * * *} \\
(-3.66)\end{array}$ & $\begin{array}{c}0.00955 \\
(1.24)\end{array}$ \\
\hline$\Delta \mathrm{REV}-\Delta \mathrm{AR}$ & $\begin{array}{c}0.0265 * * * \\
(4.05)\end{array}$ & $\begin{array}{c}0.0257 * * * \\
(3.69)\end{array}$ & $\begin{array}{c}0.0262 * * * \\
(4.15)\end{array}$ & $\begin{array}{c}0.0262 * * * * \\
(4.19)\end{array}$ & $\begin{array}{c}0.0239 * * * \\
(3.07)\end{array}$ & $\begin{array}{c}0.0218 * * * \\
(2.66)\end{array}$ \\
\hline $\mathrm{CFO}_{t-1}$ & $\begin{array}{c}0.0966 * * * \\
(7.48)\end{array}$ & $\begin{array}{c}0.145^{* * * *} \\
(9.23)\end{array}$ & $\begin{array}{c}0.0929 * * * \\
\quad(7.28)\end{array}$ & $\begin{array}{c}0.139 * * * \\
(9.10)\end{array}$ & $\begin{array}{c}0.0875 * * * \\
(7.02)\end{array}$ & $\begin{array}{c}0.145^{* * * *} \\
(11.04)\end{array}$ \\
\hline $\mathrm{CFO}$ & $\begin{array}{c}-0.775 * * * \\
(-40.60)\end{array}$ & $\begin{array}{c}-0.697 * * * \\
(-45.32)\end{array}$ & $\begin{array}{c}-0.783 * * * \\
(-40.96)\end{array}$ & $\begin{array}{c}-0.703 * * * \\
(-61.52)\end{array}$ & $\begin{array}{c}-0.791 * * * \\
(-40.92)\end{array}$ & $\begin{array}{c}-0.695 * * * \\
(-56.44)\end{array}$ \\
\hline $\mathrm{CFO}_{t+1}$ & $\begin{array}{c}0.103 * * * \\
(7.35)\end{array}$ & $\begin{array}{c}0.140 * * * \\
(13.12)\end{array}$ & $\begin{array}{c}0.101 * * * \\
(7.13)\end{array}$ & $\begin{array}{c}0.139 * * * \\
(13.27)\end{array}$ & $\begin{array}{c}0.0937 * * * \\
(6.29)\end{array}$ & $\begin{array}{c}0.139 * * * \\
(14.46)\end{array}$ \\
\hline Pre & $\begin{array}{c}0.00304 \\
(0.41)\end{array}$ & $\begin{array}{c}0.000571 \\
(0.09)\end{array}$ & $\begin{array}{c}0.000733 \\
(0.10)\end{array}$ & $\begin{array}{c}-0.00193 \\
(-0.28)\end{array}$ & $\begin{array}{c}0.00205 \\
(0.31)\end{array}$ & $\begin{array}{c}-0.000603 \\
(-0.10)\end{array}$ \\
\hline Current & $\begin{array}{c}-\mathbf{0 . 0 1 8 1} * * * * \\
(-3.38)\end{array}$ & $\begin{array}{c}-0.0174 * * * \\
(-2.92)\end{array}$ & $\begin{array}{c}-0.0200 * * * \\
(-3.56)\end{array}$ & $\begin{array}{c}-0.0204 * * * \\
(-3.11)\end{array}$ & $\begin{array}{c}-0.0241 * * * \\
(-4.30)\end{array}$ & $\begin{array}{c}-0.0229 * * * \\
(-4.15)\end{array}$ \\
\hline Post & $\begin{array}{c}-0.00511 \\
(-0.74)\end{array}$ & $\begin{array}{c}-0.00465 \\
(-0.63)\end{array}$ & $\begin{array}{c}-0.00730 \\
(-0.90)\end{array}$ & $\begin{array}{c}-0.00675 \\
(-0.76)\end{array}$ & $\begin{array}{c}-0.0155^{* *} * \\
(-2.25)\end{array}$ & $\begin{array}{c}-0.0148 * * \\
(-2.10)\end{array}$ \\
\hline Firm characteristics & Yes & Yes & Yes & Yes & Yes & Yes \\
\hline Industry fixed effects & Yes & Yes & Yes & Yes & Yes & Yes \\
\hline Country fixed effects & Yes & Yes & Yes & Yes & Yes & Yes \\
\hline Year fixed effects & Yes & Yes & Yes & Yes & Yes & Yes \\
\hline $\mathrm{N}$ & 8,734 & 8,734 & 7,379 & 7,379 & 5,894 & 5,894 \\
\hline adj. R-sq & 0.750 & 0.720 & 0.753 & 0.722 & 0.763 & 0.723 \\
\hline
\end{tabular}


Table 6 - Number Of Petitioning Firms Sample Partition

This table reports the results showing earnings management in periods around the initiation of an antidumping trade investigation when the sample is partitioned based on the number of petitioners in each case. Specifically, we designate cases in which more than two petitioners were involved into the "\# petitioners $>2$ " partition and the remaining cases into the "\# petitioner $<=2$ " partition. Columns (1) and (2) report the results for "\# petitioners $>2$ " partition and columns (3) and (4) report the results for the "\# petitioners $<=2$ " partition. TOT_ACC is measured as the change in current assets minus the change in current liabilities (adjusted for current liabilities used for financing) minus depreciation expense. WC_ACC is working capital accruals, measured as the change in current assets minus the change in current liabilities (adjusted for current liabilities used for financing). 1/TotAssets is the inverse of lagged total assets. $\mathrm{CFO}_{t-1, t, t+1}$ are cash flows from operations in year $t-1, t$ and $t+1$ scaled by lagged total assets. PP\&E is net property, plant and equipment, scaled by lagged total assets. $\triangle \mathrm{REV}-\triangle \mathrm{AR}$ is the change in sales minus the change in accounts receivable, scaled by lagged total assets. Other control variables are defined in Table 2. Standard errors are two-way clustered by both firm and year. T-statistics are presented underneath the coefficient estimates. $* * *, * *$, and $*$ denote significance levels at $1 \%, 5 \%$, and $10 \%$, respectively.

\begin{tabular}{|c|c|c|c|c|c|}
\hline & $(1)$ & $(2)$ & & (3) & (4) \\
\hline & \multicolumn{2}{|c|}{ \# petitioners $>2$} & \multicolumn{3}{|c|}{ \# petitioners $<=2$} \\
\hline & TOT_ACC & WC_ACC & & TOT_ACC & WC_ACC \\
\hline 1/TotAssets & $\begin{array}{c}0.0175 \\
(1.38)\end{array}$ & $\begin{array}{c}0.0273 * * \\
(2.39)\end{array}$ & & $\begin{array}{c}0.0209 \\
(0.99)\end{array}$ & $\begin{array}{c}0.0649 * * * \\
(3.49)\end{array}$ \\
\hline PP\&E & $\begin{array}{c}-0.0235 * * * \\
(-2.89)\end{array}$ & $\begin{array}{c}0.00343 \\
(0.48)\end{array}$ & & $\begin{array}{c}-0.0413 * * * \\
(-6.52)\end{array}$ & $\begin{array}{c}0.00579 \\
(1.01)\end{array}$ \\
\hline$\triangle \mathrm{REV}-\Delta \mathrm{AR}$ & $\begin{array}{c}0.0321 * * * \\
(3.37)\end{array}$ & $\begin{array}{c}0.0264 * * * \\
(3.06)\end{array}$ & & $\begin{array}{c}0.0265 * * * \\
(4.51)\end{array}$ & $\begin{array}{c}0.0295 \text { *** } \\
(4.78)\end{array}$ \\
\hline $\mathrm{CFO}_{t-1}$ & $\begin{array}{c}0.0839 * * * \\
(6.35)\end{array}$ & $\begin{array}{c}0.147 * * * \\
(9.77)\end{array}$ & & $\begin{array}{c}0.0964 * * * \\
(9.13)\end{array}$ & $\begin{array}{c}0.138 * * * \\
(10.23)\end{array}$ \\
\hline $\mathrm{CFO}$ & $\begin{array}{c}-0.818 * * * \\
(-39.37)\end{array}$ & $\begin{array}{c}-0.730 * * * \\
(-48.03)\end{array}$ & & $\begin{array}{c}-0.772 * * * \\
(-42.00)\end{array}$ & $\begin{array}{c}-0.712 * * * \\
(-41.82)\end{array}$ \\
\hline $\mathrm{CFO}_{t+1}$ & $\begin{array}{c}0.0821 * * * \\
(4.33)\end{array}$ & $\begin{array}{c}0.135 * * * \\
(15.95)\end{array}$ & & $\begin{array}{c}0.103 * * * \\
(8.43)\end{array}$ & $\begin{array}{c}0.136 * * * \\
(11.87)\end{array}$ \\
\hline Pre & $\begin{array}{c}0.0154 \\
(1.51)\end{array}$ & $\begin{array}{c}0.0135^{*} \\
(1.79)\end{array}$ & & $\begin{array}{c}0.00397 \\
(0.54)\end{array}$ & $\begin{array}{c}0.00214 \\
(0.34)\end{array}$ \\
\hline Current & $\begin{array}{c}-0.00429 \\
(-0.67)\end{array}$ & $\begin{array}{c}-0.00287 \\
(-0.49)\end{array}$ & & $\begin{array}{c}-0.0167 * * * \\
(-2.57)\end{array}$ & $\begin{array}{c}-0.0145 * * \\
(-2.45)\end{array}$ \\
\hline Post & $\begin{array}{c}-0.00894 \\
(-1.14)\end{array}$ & $\begin{array}{c}-0.00888 \\
(-1.06)\end{array}$ & & $\begin{array}{c}-0.00143 \\
(-0.25)\end{array}$ & $\begin{array}{c}-0.00176 \\
(-0.31)\end{array}$ \\
\hline Firm characteristics & Yes & Yes & & Yes & Yes \\
\hline Industry fixed effects & Yes & Yes & & Yes & Yes \\
\hline Country fixed effects & Yes & Yes & & Yes & Yes \\
\hline $\begin{array}{l}\text { Year fixed effects } \\
p \text {-value }\left(\beta_{\text {Current }}{ }^{T O T_{-} A C C}>\beta_{\text {Current }}{ }^{T O T_{-} A C C}\right) \\
p \text {-value }\left(\beta_{\text {Current }}{ }^{W C_{-} A C C}>\beta_{\text {Current }}{ }^{W C_{-} A C C}\right)\end{array}$ & Yes & Yes & $\begin{array}{l}0.07 \\
0.07\end{array}$ & Yes & Yes \\
\hline $\mathrm{N}$ & 4,672 & 4,672 & & 9,094 & 9,094 \\
\hline adj. R-sq & 0.781 & 0.748 & & 0.746 & 0.719 \\
\hline
\end{tabular}




\section{Table 7 - Further Evidence: Distance Between Petitioning Firms Sample Partition}

This table reports the results showing earnings management in periods around the initiation of an antidumping trade investigation when the sample is partitioned based on the median aggregate distance between the petitioners in each case for cases with at least two petitioners involved. Total distance is calculated as the sum of distances between all petitioners. Columns (1) and (2) report the results for the "Distant" partition and columns (3) and (4) report the results for the "Proximate" partition. TOT_ACC is measured as the change in current assets minus the change in current liabilities (adjusted for current liabilities used for financing) minus depreciation expense. WC_ACC is working capital accruals, measured as the change in current assets minus the change in current liabilities (adjusted for current liabilities used for financing). 1/TotAssets is the inverse of lagged total assets. $\mathrm{CFO}_{t-1, t, t+1}$ are cash flows from operations in year $t-1, t$ and $t+1$ scaled by lagged total assets. PP\&E is net property, plant and equipment, scaled by lagged total assets. $\triangle \mathrm{REV}-\triangle \mathrm{AR}$ is the change in sales minus the change in accounts receivable, scaled by lagged total assets. Other control variables are defined in Table 2. Standard errors are two-way clustered by both firm and year. T-statistics are presented underneath the coefficient estimates. $* * * * *$, and $*$ denote significance levels at $1 \%, 5 \%$, and $10 \%$, respectively.

\begin{tabular}{|c|c|c|c|c|}
\hline & $(1)$ & $(2)$ & (3) & $(4)$ \\
\hline & \multicolumn{2}{|c|}{ Distant } & \multicolumn{2}{|c|}{ Proximate } \\
\hline & TOT_ACC & WC_ACC & TOT_ACC & WC_ACC \\
\hline 1/TotAssets & $\begin{array}{c}0.0171 \\
(1.34)\end{array}$ & $\begin{array}{l}0.0275^{* *} \\
(2.26)\end{array}$ & $\begin{array}{c}0.00298 \\
(0.13)\end{array}$ & $\begin{array}{l}0.0443 * * \\
(2.02)\end{array}$ \\
\hline PP\&E & $\begin{array}{l}-0.0208 * * * \\
(-2.77)\end{array}$ & $\begin{array}{c}0.0130^{* *} \\
(1.98)\end{array}$ & $\begin{array}{c}-0.0265 * * * \\
(-3.59)\end{array}$ & $\begin{array}{c}0.00941 \\
(1.17)\end{array}$ \\
\hline$\Delta \mathrm{REV}-\Delta \mathrm{AR}$ & $\begin{array}{l}0.0308 * * * \\
\quad(3.60)\end{array}$ & $\begin{array}{l}0.0276 * * * \\
\quad(3.02)\end{array}$ & $\begin{array}{l}0.0286 * * * \\
\quad(3.23)\end{array}$ & $\begin{array}{l}0.0249^{* *} \\
(2.41)\end{array}$ \\
\hline $\mathrm{CFO}_{t-1}$ & $\begin{array}{l}0.0894 * * * \\
\quad(7.58)\end{array}$ & $\begin{array}{l}0.144 * * * \\
(9.82)\end{array}$ & $\begin{array}{l}0.0823 * * * \\
\quad(6.23)\end{array}$ & $\begin{array}{l}0.138 * * * \\
(9.26)\end{array}$ \\
\hline $\mathrm{CFO}$ & $\begin{array}{c}-0.819 * * * \\
(-55.76)\end{array}$ & $\begin{array}{c}-0.743 * * * \\
(-46.55)\end{array}$ & $\begin{array}{c}-0.828 * * * \\
(-28.12)\end{array}$ & $\begin{array}{c}-0.734 * * * \\
(-26.65)\end{array}$ \\
\hline $\mathrm{CFO}_{t+1}$ & $\begin{array}{l}0.0991 * * * \\
\quad(6.54)\end{array}$ & $\begin{array}{c}0.132 * * * \\
(11.01)\end{array}$ & $\begin{array}{l}0.0854 * * * \\
(5.17)\end{array}$ & $\begin{array}{l}0.142 * * * \\
(6.58)\end{array}$ \\
\hline Pre & $\begin{array}{l}0.0164 * * \\
(2.07)\end{array}$ & $\begin{array}{l}0.0153 * * \\
(2.02)\end{array}$ & $\begin{array}{c}-0.00935 \\
(-1.37)\end{array}$ & $\begin{array}{c}-0.00933 \\
(-1.22)\end{array}$ \\
\hline Current & $\begin{array}{c}-0.00446 \\
(-0.65)\end{array}$ & $\begin{array}{c}-\mathbf{- 0 . 0 0 2 8 5} \\
(-0.44)\end{array}$ & $\begin{array}{c}-0.0281 * * * \\
(-2.79)\end{array}$ & $\begin{array}{c}-\mathbf{0 . 0 2 5 5} * * * \\
(-3.39)\end{array}$ \\
\hline Post & $\begin{array}{c}-0.0122 \\
(-1.49)\end{array}$ & $\begin{array}{c}-0.0140 \\
(-1.43)\end{array}$ & $\begin{array}{c}-0.0178 * * \\
(-2.54)\end{array}$ & $\begin{array}{r}-0.0131 \\
(-1.50)\end{array}$ \\
\hline Firm characteristics & Yes & Yes & Yes & Yes \\
\hline Industry fixed effects & Yes & Yes & Yes & Yes \\
\hline Country fixed effects & Yes & Yes & Yes & Yes \\
\hline $\begin{array}{l}\text { Year fixed effects } \\
p \text {-value }\left[\beta_{\text {Current }}{ }^{(3)}<\beta_{\text {Current }}{ }^{\left({ }^{1}\right)}\right]\end{array}$ & Yes & Yes & $\begin{array}{l}\text { Yes } \\
<0.01\end{array}$ & Yes \\
\hline$p$-value $\left[\beta_{\text {Current }}{ }^{(4)}<\beta_{\text {Current }}{ }^{(2)}\right]$ & & & & $<0.01$ \\
\hline $\mathrm{N}$ & 4,665 & 4,665 & 5,041 & 5,041 \\
\hline adj. R-sq & 0.787 & 0.752 & 0.780 & 0.734 \\
\hline
\end{tabular}




\section{Table 8 - Retaliation Capacity Sample Partition}

This table reports the results showing earnings management in periods around the initiation of an antidumping trade investigation when the sample is partitioned based on the ratio of total value of exports from the petitioning firm's home country to the defendant countries over the total value of exports by the petitioning firm's home country. We designate cases in which this ratio is lower than the sample median into the low export partition (i.e., low retaliation capacity partition) and cases in which the ratio is higher than the sample median into the high export partition (i.e., high retaliation capacity partition), respectively. Columns (1) and (2) report the results for the low retaliation capacity partition and columns (3) and (4) report the results for the high retaliation capacity partition. TOT_ACC is measured as the change in current assets minus the change in current liabilities (adjusted for current liabilities used for financing) minus depreciation expense. WC_ACC is working capital accruals, measured as the change in current assets minus the change in current liabilities (adjusted for current liabilities used for financing). 1/TotAssets is the inverse of lagged total assets. CFO $t-1, t, t+1$ are cash flows from operations in year $t-1, t$ and $t+1$ scaled by lagged total assets. PP\&E is net property, plant and equipment, scaled by lagged total assets. $\triangle \mathrm{REV}-\triangle \mathrm{AR}$ is the change in sales minus the change in accounts receivable, scaled by lagged total assets. Other control variables are defined in Table 2. Standard errors are two-way clustered by both firm and year. T-statistics are presented underneath the coefficient estimates. ***,**, and * denote significance levels at $1 \%, 5 \%$, and $10 \%$, respectively.

\begin{tabular}{|c|c|c|c|c|}
\hline & $(1)$ & $(2)$ & (3) & $(4)$ \\
\hline & \multicolumn{2}{|c|}{ Low retaliation capacity } & \multicolumn{2}{|c|}{ High retaliation capacity } \\
\hline & TOT_ACC & WC_ACC & TOT_ACC & WC_ACC \\
\hline 1/TotAssets & $\begin{array}{c}0.0373 * \\
(1.88)\end{array}$ & $\begin{array}{c}0.0542 * * * \\
(3.19)\end{array}$ & $\begin{array}{c}0.0184 \\
(1.57)\end{array}$ & $\begin{array}{c}0.0369 * * * \\
(3.39)\end{array}$ \\
\hline PP\&E & $\begin{array}{c}-0.0361 * * * \\
(-5.65)\end{array}$ & $\begin{array}{c}0.00466 \\
(0.71)\end{array}$ & $\begin{array}{c}-0.0321 * * * \\
(-4.52)\end{array}$ & $\begin{array}{c}0.0138 * * \\
(2.26)\end{array}$ \\
\hline$\Delta \mathrm{REV}-\Delta \mathrm{AR}$ & $\begin{array}{c}0.0246 * * * \\
(3.72)\end{array}$ & $\begin{array}{c}0.0298 * * * * \\
(4.49)\end{array}$ & $\begin{array}{c}0.0337 * * * \\
(5.12)\end{array}$ & $\begin{array}{c}0.0267 * * * \\
(3.57)\end{array}$ \\
\hline $\mathrm{CFO}_{t-1}$ & $\begin{array}{c}0.0901 * * * \\
(9.68)\end{array}$ & $\begin{array}{c}0.120 * * * \\
(9.54)\end{array}$ & $\begin{array}{c}0.101 * * * \\
(8.40)\end{array}$ & $\begin{array}{c}0.157 * * * \\
(11.24)\end{array}$ \\
\hline $\mathrm{CFO}$ & $\begin{array}{c}-0.776 * * * \\
(-39.37)\end{array}$ & $\begin{array}{c}-0.725 * * * \\
(-41.57)\end{array}$ & $\begin{array}{c}-0.794 * * * \\
(-44.58)\end{array}$ & $\begin{array}{c}-0.722 * * * \\
(-53.95)\end{array}$ \\
\hline $\mathrm{CFO}_{t+1}$ & $\begin{array}{c}0.110 * * * \\
(9.37)\end{array}$ & $\begin{array}{c}0.130 * * * \\
(11.25)\end{array}$ & $\begin{array}{c}0.0921 * * * * \\
(6.18)\end{array}$ & $\begin{array}{c}0.137 * * * \\
(12.65)\end{array}$ \\
\hline Pre & $\begin{array}{c}0.0114 \\
(1.52)\end{array}$ & $\begin{array}{c}0.00601 \\
(0.79)\end{array}$ & $\begin{array}{c}0.00213 \\
(0.47)\end{array}$ & $\begin{array}{c}0.00398 \\
(0.72)\end{array}$ \\
\hline Current & $\begin{array}{c}-0.00674 \\
(-0.84)\end{array}$ & $\begin{array}{c}-0.00594 \\
(-0.88)\end{array}$ & $\begin{array}{c}-0.0217 * * * \\
(-3.57)\end{array}$ & $\begin{array}{c}-0.0188 * * * \\
(-2.98)\end{array}$ \\
\hline Post & $\begin{array}{c}-0.00865 \\
(-1.16)\end{array}$ & $\begin{array}{c}-0.00943 \\
(-1.32)\end{array}$ & $\begin{array}{c}-0.0110 * \\
(-1.67)\end{array}$ & $\begin{array}{c}-0.00775 \\
(-1.11)\end{array}$ \\
\hline Firm characteristics & Yes & Yes & Yes & Yes \\
\hline Industry fixed effects & Yes & Yes & Yes & Yes \\
\hline Country fixed effects & Yes & Yes & Yes & Yes \\
\hline Year fixed effects & Yes & Yes & Yes & Yes \\
\hline$p$-value $\left[\beta_{\text {Current }}{ }^{(3)}<\beta_{\text {Current }}{ }^{(1)}\right]$ & & & 0.03 & \\
\hline$p$-value $\left[\beta_{\text {Current }}{ }^{(4)}<\beta_{\text {Current }}{ }^{(2)}\right]$ & & & & 0.05 \\
\hline $\mathrm{N}$ & 7,185 & 7,185 & 6,673 & 6,673 \\
\hline adj. R-sq & 0.748 & 0.726 & 0.767 & 0.742 \\
\hline
\end{tabular}




\section{Table 9 - Financing Sample Partition}

This table reports the results showing earnings management in periods around the initiation of an antidumping trade investigation when the sample is partitioned based on the legal status of the firm whether or not the firm raises new financing in the year of, year before, and/or the year after the initiation. Columns (1) and (2) report the results for firms that raise cumulative new debt or equity greater than 5\% of total assets and columns (3) and (4) report the results for firms that do not raise cumulative new debt or equity greater than 5\% of total assets. TOT_ACC is measured as the change in current assets minus the change in current liabilities (adjusted for current liabilities used for financing) minus depreciation expense. WC_ACC is working capital accruals, measured as the change in current assets minus the change in current liabilities (adjusted for current liabilities used for financing). 1/TotAssets is the inverse of lagged total assets. CFO $t$ $1, t, t+1$ are cash flows from operations in year $t-1, t$ and $t+1$ scaled by lagged total assets. PP\&E is net property, plant and equipment, scaled by lagged total assets. $\triangle \mathrm{REV}-\triangle \mathrm{AR}$ is the change in sales minus the change in accounts receivable, scaled by lagged total assets. Other control variables are defined in Table 2 . Standard errors are two-way clustered by both firm and year. T-statistics are presented underneath the coefficient estimates. ***, **, and * denote significance levels at $1 \%, 5 \%$, and $10 \%$, respectively.

\begin{tabular}{|c|c|c|c|c|}
\hline & (1) & (2) & (3) & (4) \\
\hline & \multicolumn{2}{|c|}{ With new financing } & \multicolumn{2}{|c|}{ Without new financing } \\
\hline & TOT_ACC & WC_ACC & TOT_ACC & WC_ACC \\
\hline 1/TotAssets & $\begin{array}{c}0.0274 * * \\
(2.51)\end{array}$ & $\begin{array}{c}0.0467 * * * \\
(4.11)\end{array}$ & $\begin{array}{c}0.0248 \\
(1.45)\end{array}$ & $\begin{array}{c}0.0404 * * * \\
(3.35)\end{array}$ \\
\hline PP\&E & $\begin{array}{c}-0.0332 * * * \\
(-4.56)\end{array}$ & $\begin{array}{c}0.00937 \\
(1.41)\end{array}$ & $\begin{array}{c}-0.0366 * * * \\
(-5.17)\end{array}$ & $\begin{array}{c}0.00262 \\
(0.39)\end{array}$ \\
\hline$\triangle \mathrm{REV}-\Delta \mathrm{AR}$ & $\begin{array}{l}0.0267 * * * \\
\quad(3.86)\end{array}$ & $\begin{array}{l}0.0261 * * * \\
\quad(3.82)\end{array}$ & $\begin{array}{l}0.0282 * * * \\
\quad(3.29)\end{array}$ & $\begin{array}{l}0.0295 * * * \\
\quad(3.11)\end{array}$ \\
\hline $\mathrm{CFO}_{t-1}$ & $\begin{array}{l}0.0829 * * * \\
\quad(6.78)\end{array}$ & $\begin{array}{c}0.124 * * * \\
(8.00)\end{array}$ & $\begin{array}{c}0.105 * * * \\
(7.33)\end{array}$ & $\begin{array}{c}0.152 * * * \\
(10.13)\end{array}$ \\
\hline $\mathrm{CFO}$ & $\begin{array}{c}-0.813 * * * \\
(-50.58)\end{array}$ & $\begin{array}{c}-0.748 * * * \\
(-51.95)\end{array}$ & $\begin{array}{c}-0.767 * * * \\
(-40.70)\end{array}$ & $\begin{array}{c}-0.689 * * * \\
(-43.58)\end{array}$ \\
\hline $\mathrm{CFO}_{t+1}$ & $\begin{array}{c}0.104 * * * \\
(7.14)\end{array}$ & $\begin{array}{c}0.135^{* * *} \\
(10.90)\end{array}$ & $\begin{array}{l}0.0994 * * * \\
\quad(7.52)\end{array}$ & $\begin{array}{c}0.134 * * * \\
(12.35)\end{array}$ \\
\hline Pre & $\begin{array}{c}-0.00120 \\
(-0.14)\end{array}$ & $\begin{array}{c}0.000859 \\
(0.12)\end{array}$ & $\begin{array}{r}0.0113 \\
(1.37)\end{array}$ & $\begin{array}{c}0.00586 \\
(0.68)\end{array}$ \\
\hline Current & $\begin{array}{c}-0.0106 \\
(-1.24)\end{array}$ & $\begin{array}{c}-0.00646 \\
(-0.84)\end{array}$ & $\begin{array}{c}-0.0198 * * * \\
(-3.10)\end{array}$ & $\begin{array}{c}-0.0183 * * * \\
(-2.73)\end{array}$ \\
\hline Post & $\begin{array}{c}-0.00451 \\
(-0.60)\end{array}$ & $\begin{array}{c}-0.00406 \\
(-0.52)\end{array}$ & $\begin{array}{c}-0.00750 \\
(-1.49)\end{array}$ & $\begin{array}{c}-0.00579 \\
(-1.01)\end{array}$ \\
\hline Firm characteristics & Yes & Yes & Yes & Yes \\
\hline Industry fixed effects & Yes & Yes & Yes & Yes \\
\hline Country fixed effects & Yes & Yes & Yes & Yes \\
\hline $\begin{array}{l}\text { Year fixed effects } \\
p \text {-value }\left[\beta_{\text {Current }}{ }^{\left({ }^{3}\right)}<\beta_{\text {Current }}{ }^{(1)}\right]\end{array}$ & Yes & Yes & $\begin{array}{l}\text { Yes } \\
0.10\end{array}$ & Yes \\
\hline$p$-value $\left[\beta_{\text {Current }}{ }^{(4)}<\beta_{\text {Current }}{ }^{(2)}\right]$ & & & & 0.06 \\
\hline $\mathrm{N}$ & 6,501 & 6,501 & 7,391 & 7,391 \\
\hline adj. R-sq & 0.775 & 0.744 & 0.750 & 0.715 \\
\hline
\end{tabular}




\section{Table 10 - Legal Enforcement And Regulatory Quality Sample Partitions}

This table reports the results showing earnings management in periods around the initiation of an antidumping trade investigation when the sample is partitioned based on legal enforcement and regulatory quality. We measure legal enforcement as the average of rule of law and judicial impartiality, calculated by La Porta et al. (2002) and regulatory quality as in Kaufmann et al. (2009). Columns (1)-(4) report the results when the sample is partitioned based on legal enforcement and columns (5)-(8) report the results when the sample is partitioned based on regulatory quality. TOT_ACC is measured as the change in current assets minus the change in current liabilities (adjusted for current liabilities used for financing) minus depreciation expense. WC_ACC is working capital accruals, measured as the change in current assets minus the change in current liabilities (adjusted for current liabilities used for financing). 1/TotAssets is the inverse of lagged total assets. $\mathrm{CFO}_{t-1, t, t+1}$ are cash flows from operations in year $t-1, t$ and $t+1$ scaled by lagged total assets. PP\&E is net property, plant and equipment, scaled by lagged total assets. $\Delta \mathrm{REV}-\Delta \mathrm{AR}$ is the change in sales minus the change in accounts receivable, scaled by lagged total assets. Other control variables are defined in Table 2 . Standard errors are two-way clustered by firm and year. T-statistics are presented underneath the coefficient estimates. $* * *, * *$, and $*$ denote significance levels at $1 \%, 5 \%$, and $10 \%$, respectively.

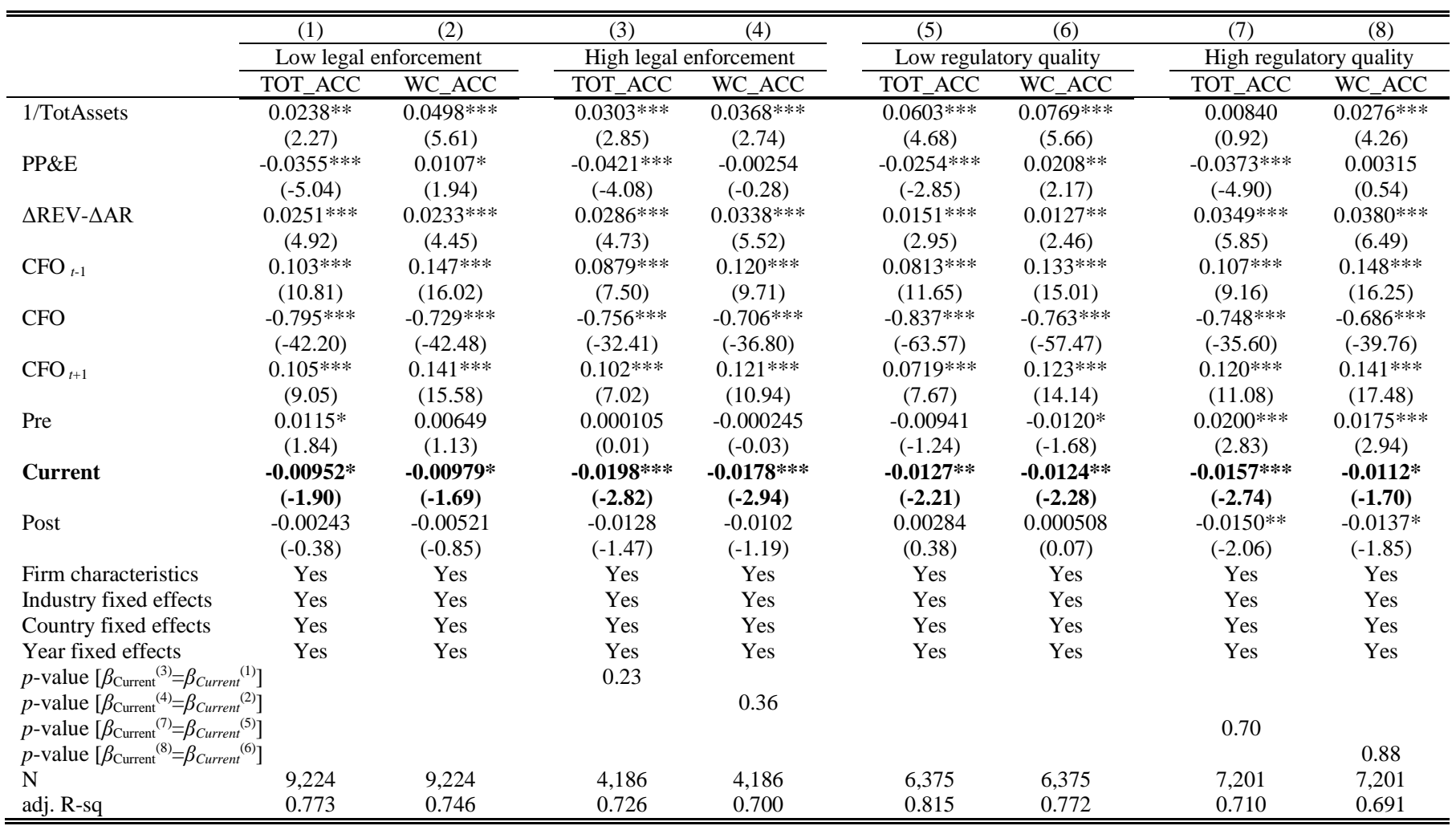


Table 11 - Audit And Financial Reporting Enforcement Intensity Sample Partitions

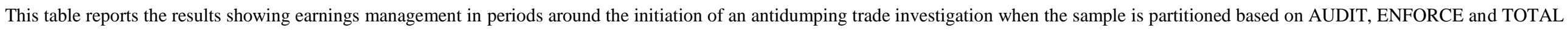

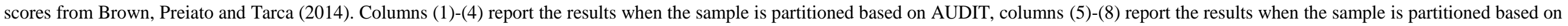

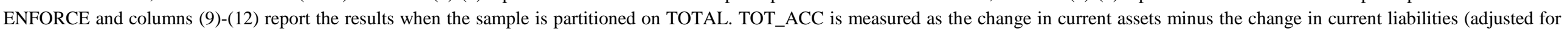

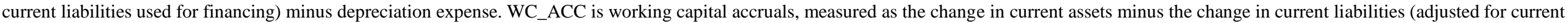

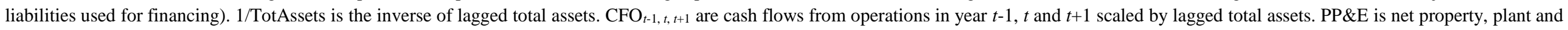

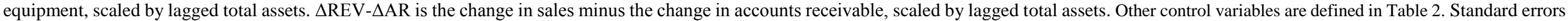
are two-way clustered by both firm and year. T-statistics are presented underneath the coefficient estimates. $* * * * *$, and $*$ denote significance levels at $1 \%, 5 \%$, and $10 \%$, respectively.

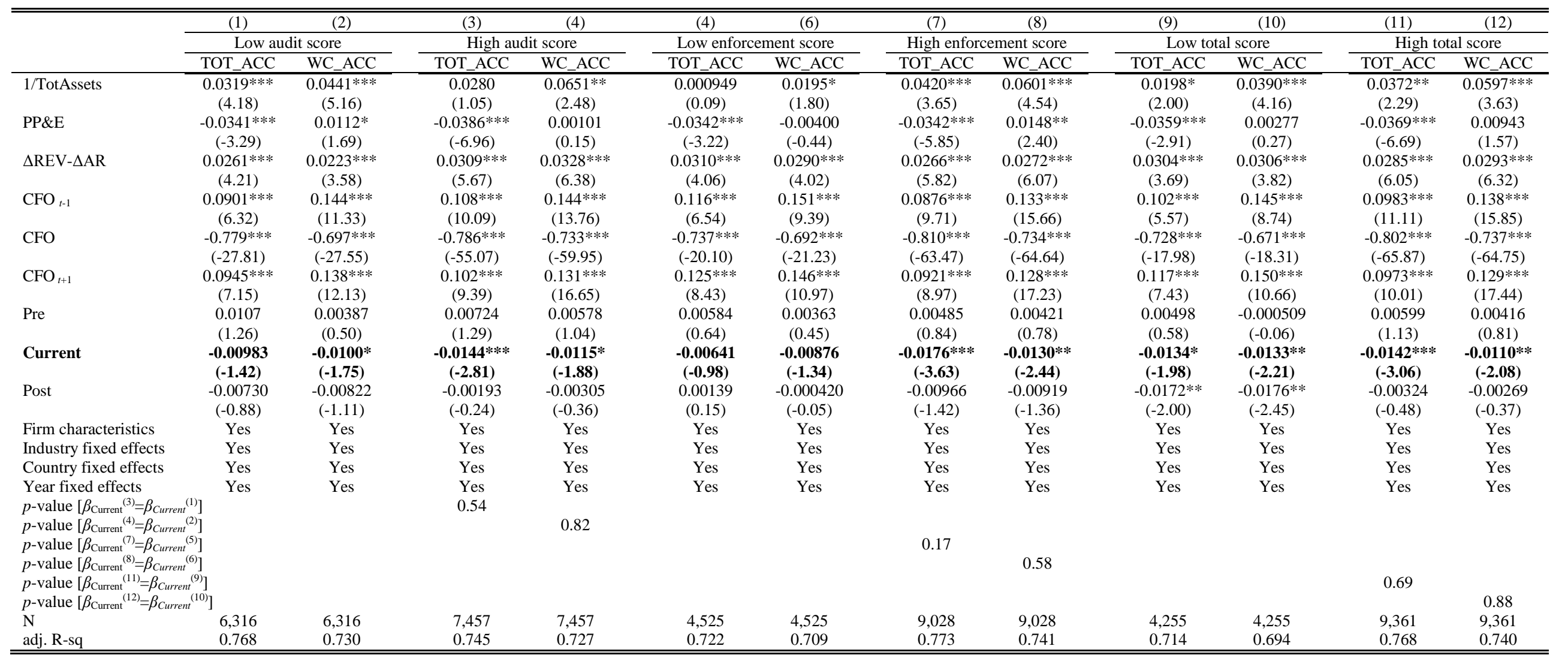

